\title{
THE FORGING OF A STRIKE FORCE (PART I)
}

\author{
CENTRAL THEMES IN THE HISTORY OF THE SOUTH AFRICAN ARMY 1980-1990
}

\author{
by Dr S Monick*
}

Photographs by author (exept where otherwise stated)

\section{THE 1980s: THE SADF ASSUMES A HIGH PROFILE AND AGGRESSIVE IMAGE}

The principal theme in this article is an analysis of the central shaping forces in the operational history of the South African Army during the period 19801990.' These forces are embodied in the revolutionary developments within artillery (exemplified by the $G 5$ and G6) and the advent of mechanized infantry. These huge technological strides, unprecedented in the history of South Africa's armed forces, implied the most far reaching repercussions; specifically, in terms of a combination of vastly enhanced mobility and striking power, in which artillery and infantry served as an integrated strike foce. The background, and indeed motivation, underlying such developments was an intense phase of military activity, initiated in 1975 (in the form of South Africa's - albeit limited - intervention in the Angolan civil war on behalf of the coalition opposed to the ruling MPLA, the role of the SADF being designated Operation Savannah), and began to gather full momentum in 1978 .

This post Operation Savannah phase has been referred to in a previous article by the author (1):

'In 1975 the SADF assumed responsibility for the military security of South West Africa (as that territory was then designated). Initially, a defensive posture was adopted in response to the SWAPO-led insur- gency. However, commencing in 1978 a far more aggressive policy manifested itself: expressed in the cross-border pre-emptive raids directed against SWAPO bases in Angola. The approach was motivated by the realization that the only truly effective method of defeating SWAPO was to strike at that organization's rear bases, disrupting the insurgents' logistic communications and other facilities and thus preempting their ability to wage guerrilla warfare within South West Africa. The policy attained expression in a series of spectacularly successful attacks by highly mobile SADF task forces, directed against SWAPO bases...'

The full list of these operations is as follows: ${ }^{2}$

Reindeer (4-5 May 1978)

Safraan (6-11 March 1979)

Rekstok (6-15 March 1979)

Sceptic (Smokeshell) (30 May-30 June 1980)

Klipkop (2 August 1980)

Protea (23 August-10 September 1981) Carnation (1981)

Daisy (1 November-20 November 1981)

Super (13 March 1982)

Mebos (July-August 1982)

Askari (6 September 1983-13 January 1984)

J.M.C. (19 February 1984-25 May 1985)

Boswilger (26 June-1 July 1985)

Egret (16-23 September 1985)

Firewood (31 October-4 November 1986)

Modular (August-December 1987)

Hooper (13 January 1988-26 February 1988)

Packer (26 February 1988-30 April 1988)

Displace (30 April 1988-29 August 1988).

' As the title implies, this theme is centred upon the South African Army. To endeavour to encompass the Air Force and Navy within the scope of the study would involve one of two serious disadvantages, both centred upon the problem of space. The first would necessarily involve a diffused, outline approach to the entire subject, and the dimensions of force and concentration would be lost. Alternatively, if all arms of the SADF received equally detailed treatment during the period under review, the length would impose a wearisome burden upon the readers. Accordingly, the focus of the article is directed upon the South African army; more specifically, its infantry and artillery arms.

${ }^{2}$ The writer is indebted to Mr Richard Henry, of the South African National Museum of Military History, for furnishing a complete list of these operations, and for so meticulously and conscientously collating the documentation relating to them. 


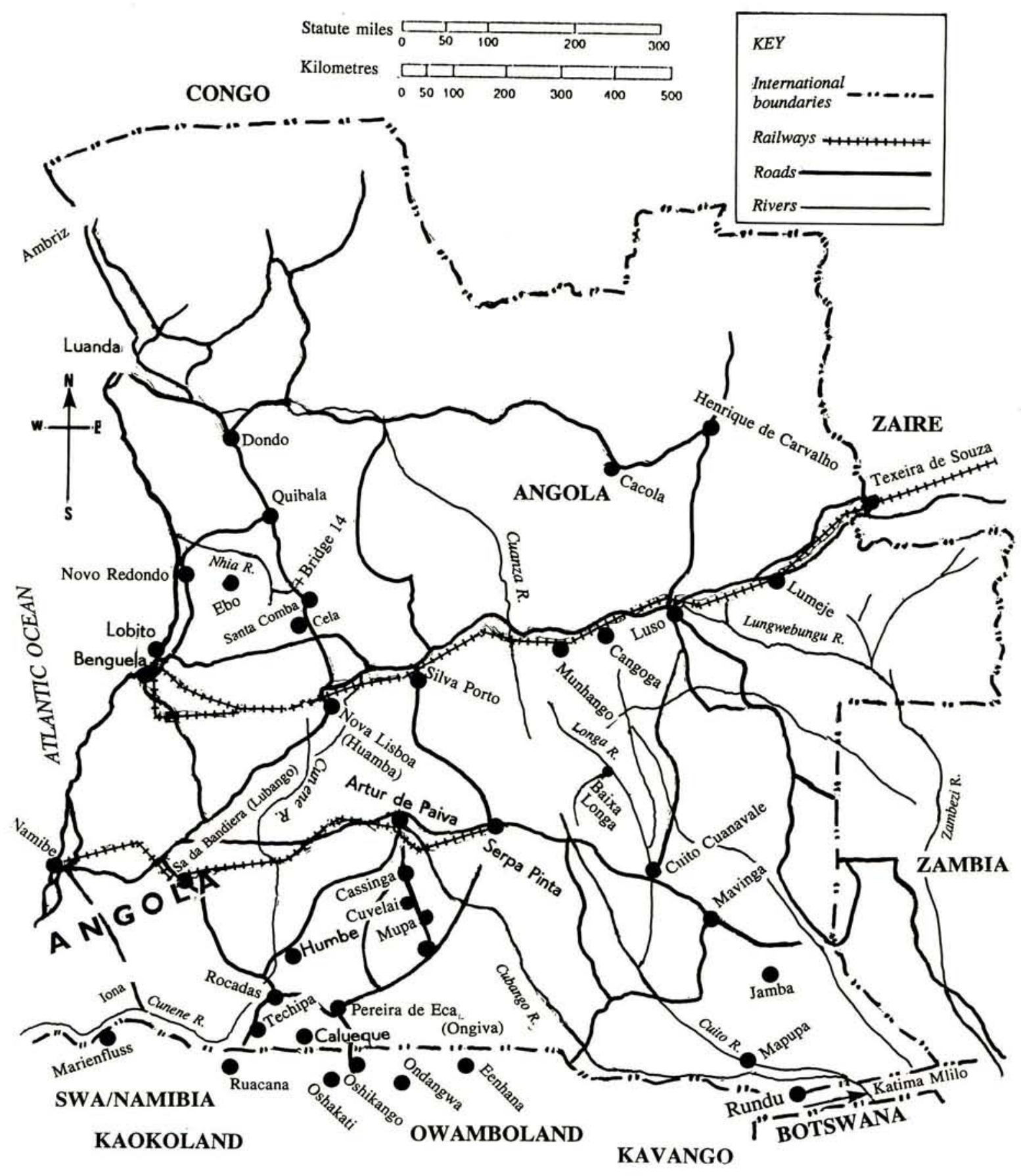




\section{PART I: STRIKES INTO ANGOLA}

In so far as the offensive strategy adopted by the SADF during the period 1978-1989 is intimately related to the far reaching technological innovations absorbed by the armed forces, it is necessary to furnish some detail of the operations referred to above. Such an approach must, of necessity, be highly selective; due to the constraints of space within an article which must, unavoidably, be of some length. Accordingly, it has been decided to select, for detailed treatment, operations which were executed at various intervals spanning the 1980s; viz Operations Protea (1981), Askari (19831984), Modular, Hooper, Packer and Displace (spanning the period 19871988, which are discussed collectively, and which signal the end of the South African military incursions into Angola).

\section{OPERATION PROTEA (1981)}

Operation Protea, spanning the period 20 August-10 September 1981, was directed against the SWAPO insurgent bases of southern Angola, in the Xangongo area. The operation was the culmination of a series of seek and destroy actions against the aforementioned bases. In the preceding actions the Security Forces had skirted around kraals, villages and administrative centres without interference from MPLA forces. In one instance, troops on the track of SWAPO terrorists approached within a few hundred metres of Ongiva without clashing with Angolan military forces, civilians or officials. However, the planned action against SWAPO bases in the Xangongo region contained the very real threat of such a clash occurring. This potential source of conflict derived from the fact that the Russian advised SWAPO and MPLA military forces (the latter designated Fapla) were virtually integrated, their camps being indistinguishable. Thus, the planning encompassed the scenario of a South African vs Angolan military conflict.

Two task forces were established. The one contained mechanized and motorized infantry, who would thus be able to respond to any conventional forces ranged against the South Africans. The other force was designed to operate on foot and participate in COIN (counter-insurgency) operations; engaged in search and destroy actions. On 24 August 1981 one force entered Angola west of the Cunene River, advancing towards Xangongo from the west; whilst the second element moved into Angola to the east of Xangongo.

Angolan forces, despite being warned by air-dropped leaflets, attempted to intervene, and several fierce fire fights erupted in the environs of Xangongo. SWAPO and Fapla personnel wore identical uniforms, in accordance with a government regulation intended to conceal the presence of SWAPO terrorists from the non-combatant population. This rendered it impossible to distinguish between regular MPLA forces and their SWAPO 'guests'. Every possible measure was adopted to avoid the civilian sector of the town. and civilians were warned by leaflets and loudhailers to vacate the area prior to the action.

\section{Enemy losses and Soviet casualties}

Operation Protea represented the largest mechanized operation undertaken by the SADF since the conclusion of World War II. The enemy's entire logistical system in southern Angola was destroyed.

The great success of the operation was graphically and unequivocally demonstrated by enemy losses and the vast quantity of captured materiel. With regard to the former, combined SWAPO and Fapla losses amounted to approximately 1000 , and some 28 prisoners were taken. Ten members of the SADF were killed.

Four Russians were killed in company with Angolan-SWAPO personnel. All were wearing Angolan military uniforms. They were: Lt Col Yevgnenii Victorovich Kireev, an artillery adviser; Lt Col Joseph Lamonovich (surname unknown), adviser to the polital commissar; and two women (the wives of $\mathrm{L} t$ Col Kireev and WO Pestretsov). Their deaths could have been averted had the convoy in which they were travelling heeded the attempts of the Security Forces to communicate with it. The convoy made a break to the north east from Ongiva as dusk was gat- 
hering and blindly rushed at the South African troops who had been positioned to cut off escapes to the north east. Whilst these endeavours to communicate were being made, the enemy convoy commenced enveloping movements, endeavouring to skirt around both flanks of the Security Force troops. The South African company commander called for air support, and several enemy vehicles were destroyed. Two further vehicles were destroyed by ground troops. Darkness intervened and the firefight ended. By dawn of the following day, those who had not been killed had made their escape.

The presence of Soviet military advisers, stationed at Xangongo and Ongiva, was further proved by the capture of a Russian Warrant Officer, Nicolai Feodorovich Petresov (whose wife, to reiterate, had been killed) when a column of 25 vehicles, including tanks, attempted to escape from Ongiva as South African and South West African Security Forces were in the process of capturing that town. Other Soviet personnel known to have been stationed at Xangongo or Ongiva were: Lt Col Feodr Antonovich Zhubrzhytsky, an 'adviser' to Fapla, and his wife: Maj Yuri Ivanovich Yegorov and his wife: Maj Anatoli Josephovich Poznakhiro: Maj Alexai Khoyerka and his wife; and Maj Vladimir Feodorovich Setenko.

\section{Captured materiel}

A huge quantity of captured materiel accompanied the task forces on their return to South West Africa; sufficient, indeed, to equip a small army. The enemy equipment included SAM-7 missiles and launchers, amphibious tanks and the latest Yugoslav $20 \mathrm{~mm}$ triple-barrelled anti-aircraft gun; as well as a vast amount of small arms which included machine guns, sub-machine guns and rifles. The Soviet supplied weaponry was displayed at Oshakati, Headquarters of Sector 10 of the Operational Area, and occupied several thousand square metres. Its value was estimated at some R200 million.

The Ratel and the role of the SAAF

Two significant features of Operation Protea were the roles of the Ratel and the SAAF. With regard to the former, the infantry fighting vehicle proved that it could match the capability of Russian supplied tanks during the operation.

The South African Air Force played a key role in the operation, the SAAF's principal tasks being the provision of air cover for ground troops. However, it also performed a vitally important preliminary function. During previous operations it had been found that Angolan early warning radar systems were alerting SWAPO anti-aircraft gun crews, and this was again confirmed in the early stages of Operation Protea. In order to provide freedom of movement for South African aircraft during the support operations, it was thus necessary to neutralize the radar installations alerting SWAPO. This necessarily implied also the elimination of the air defences protecting these systems. Both tasks were accomplished by the SAAF with most admirable efficiency.

\section{OPERATION ASKARI (1983-1984)}

Operation Askari spanned the period 6 December 1983-13 January 1984 and was launched in order to pre-empt a planned infiltration of South West Africa by seven companies of SWAPO insurgents, totalling approximately 1000 men. Originally planned as a COIN search-and-destroy mission, the operation assumed a more conventional character as Security Forces reacted in self-defence against combined Cuban, Fapla and SWAPO attacks, the assailants being equipped with Soviet supplied equipment (cf Part II). A marked characteristic of Askari was the protection afforded to SWAPO insurgents by the Angolan army and Cubans, there being strong evidence of direct Soviet guidance and leadership.

\section{Pre-empting a major SWAPO offensive}

Whilst Operation Askari was in progress several press briefings were issued by Defence $H Q$ in Pretoria, as soon as it was evident that security was not endangered. At a press conference held on 29 December 1983, presided over by Gen Viljoen and Lt Gen Gleeson, the former elucidated the motivation underlying the incursion into Angola. $\mathrm{He}$ stated that the pattern of SWAPO 
terrorist incidents during the past several years had revealed a peak in the first quarter of every year; including murder, abductions, sabotage, minelaying and contact with the Security Forces in the northern sectors of South West Africa. The principal reason for the recurrence of this time schedule was the utilization by the insurgents of the rainy season as cover, the major incursions being effected by groups ranging in numbers from 100 to 600 . The pattern was repeating itself towards the end of 1983, indications pointing to a SWAPO escalation in strength preparatory to incursions early in 1984. Intelligence indicated that as many as 1000 terrorists were being assembled, retrained and prepared for the intended infiltration; with Lubango once again being used as the SWAPO Headquarters, from whence a new campaign would be controlled. Lt Gen Gleeson also stated that the region which was the subject of South African attacks accommodated not only the HQ of SWAPO's 'central area' but also elements of such units as the 'Moscow Battalion', the 'Red Square unit', the 'Bravo' and 'Shield Battalions'; in addition to seven companies which were to spearhead the planned incursion.

This information (confirmed during Operation Askari) that SWAPO was conforming to its familiar pattern, and deploying a force hitherto unprecedented in strength, rendered it imperative 'to engage in a pre-emptive operation against the their latest offensive' (to quote the words of Gen Viljoen at the above cited press conference). Gen Viljoen stated that intelligence reports concerning the forthcoming SWAPO offensive were proven to be correct when seven companies of insurgents were off-loaded from heavy military vehicles south-east of Jamba and advanced initially east. and then subsequently south towards South West Africa, from Angola. These movements unequivocally pointed to the initiation of SWAPO's 1984 offensive.

The nerve centre of the South African offensive was the SWAPO 'defence headquarters'; and a well dug-in complex in an area measuring some 500 metres square, close to the heavily guarded Lubango airfield. Surrounding the $\mathrm{HQ}$ area were zones named: the Leningrad area; the Greenwell Matambo Training Centre; and the Marxist Training centre used for indoctrination purposes. Other SWAPO facilities included a main logistical base, a vehicle workshop, a transit base and a small logistics site.

\section{Bombing raids}

On the morning of 29 December 1983 , four SAAF aircraft bombed the $\mathrm{HQ}$ area with pinpoint accuracy. The purpose of these bombing raids was to disrupt SWAPO's ability to control operations (including the new offensive). Total surprise was achieved and all aircraft returned unscathed. Also attacked by the SAAF was another static SWAPO infrastructure; the 'western front' $\mathrm{HQ}$ near Cahama, some 200 insurgents occupying a base close to this $H Q$. When the SAAF attack commenced, the terrorists, it was reported by the local population of the area, fled to Cahama.

\section{Sophisticated enemy anti-aircraft de- fences}

During air reconnaissance missions to locate the 'western front' $\mathrm{HQ}$, heavy anti-aircraft fire was experienced by SAAF crews against whose aircraft the latest Soviet anti-aircraft missiles were launched. Tangible proof of the presence of SAM-9 missiles deployed in that region was dramatically illustrated when the head of one such missile was found in the tail of one of the Impalas engaged in the aerial reconnaissance. Also in the Cahama area, SAM-8 missiles were fired fruitlessly against SAAF aircraft. These missile sites were totally eliminated by artillery and aircraft bombardment.

\section{Search and destroy operations}

Simultaneously, search-and-destroy missions were relentlessly executed by South African ground forces in a region some three-quarters of the size of the United Kingdom; an area, moreover, characterized by dense vegetation, a virtual absence of all roads (the rainy season, furthermore, rendering movement and tracking extremely difficult) 
and sparsely populated. The strategy centred upon the pinpointing of terrorists who were removed from the protection of Fapla cover. Some 60 terrorists were killed in isolated skirmishes. The South African approach was also directed towards locating caches of arms planted in advance of the planned incursion. Lacking vehicles to transport them, SWAPO adopted the practice of concealing weapons (especially mines) along their infiltration routes. At the press conference of 29 December 1983, referred to above. Gen Viljoen stated that the number of troops on the ground did not extend beyond one platoon for every 45 square kilometres; and, whilst the object was to thwart the planned incursion, the possibility that small groups of insurgents might break through the cordon and successfully cross the border into South West Africa could not be discounted. It was also feasible that the terrorists might retreat deep into the interior of Angola, and try once again to infiltrate South West Africa.

A political commissar, captured at Cuvelai (cf below) stated that the COIN operations of the South African forces had proved so successful that a large segment of SWAPO forces had returned to their rear bases, in order to avoid becoming trapped in clashes with the Security Forces. They even feared that their bases deep within the Angolan interior would be attacked by the SADF.

\section{Cuvelai}

Details of the action at Cuvelai were furnished in a statement issued during the early hours of 7 January 1984, followed by a press conference. On 3 January a combined Cuban and Angolan force attacked Security Forces whilst the latter were conducting operations against elements of SWAPO's seven companies in the area of $\mathrm{Cu}$ velai, a hamlet. The enemy assault occurred whilst Security Forces were operating against a SWAPO base and tactical $\mathrm{HQ}$ some four $\mathrm{km}$ north-east of Cuvelai. It was subsequently revealed that the SWAPO leader element was headquartered at Cuvelai, housed with their Cuban and Angolan counterparts. Further, the movement of the seven companies, referred to above, was planned and controlled from this headquarters. Cuvelai also served as an important logistic storage area and the Security Forces captured large quantities of weapons and ammunition. For all the above reasons, Cuvelai formed a keypoint in SWAPO's offensive in South West Africa; a point confirmed by the captured SWAPO commissar (cf above).

The SWAPO-Cuban attack, characterized by a markedly aggressive spirit. spanned the period 3-6 January 1984. The attack was successfully repulsed and a total of 324 of the enemy killed. The casualties included not only SWAPO, but also Cuban soldiers; two battalions of the latter serving as reinforcements at Cuvelai. The successful South African response was seriously disadvantaged by the poor weather conditions, which reduced the countryside, in many regions, to a rain sodden quagmire (through which the SADF forces had to effect a painfully slow withdrawal into South West Africa). An especially noteworthy feature of the engagement was the dominant role played by enemy armour; specifically T54 tanks, of which 11 were destroyed by the Security Forces. A Russian tank was responsible for the most serious loss incurred by the South Africans, in terms of equipment. This was a Ratel infantry combat vehicle, destroyed whilst its guns were in action against the enemy; after being trapped in a minefield. It was destroyed by the T54, the shells of which struck the Ratel broadside, killing five members of the crew.

At a media briefing held on 13 January 1984. Maj Gen (later Lt Gen) Meiring (then GOC of the SWA Territory Force. subsequently Chief of the Army) briefed the press. He stated that at Cuvelai the South African strength consisted, essentially, of one battle group, which had to confront an entire brigade; including a company of tanks, which was annihilated. The SADF task force was outnumbered by five to one in that sector.

\section{Quiteve and Caiundo}

At the press meeting of 13 January 1984 Maj Gen Meiring also briefed the 
press concerning actions at Quiteve and in the Caiundo sector. With regard to the former he stated:

'We also acted against certain SWAPO elements in the township of Quiteve. It is not even a hamlet, just a point on the map... one little shack. We were attacked by forces from Mulondo. These forces were also repulsed. We stabilized the area round Quiteve and subsequently withdrew from the area.'

Referring to the engagement in the area of Caiundo, Maj Gen Meiring remarked:

'Towards the east we were acting against one of the known routes. We sent a reconnaissance element up. About $12 \mathrm{~km}$ from the township of Caiundo this element fell into an ambush by Fapla forces. We lost some people there and one was captured. We reacted by bombing and strafing the enemy forces in and around the township. We also subsequently withdrew from that area.

\section{Concluding observations on Operation Askari}

In the course of Operation Askari the Security Forces lost 21 men killed in return for an estimated 400-500 enemy dead (324 being lost in a single battle, Cuvelai; cf above) and also destroyed a number of Soviet tanks and other equipment, including anti-aircraft installations. Several tons of enemy weaponry were captured; items which could not be moved being destroyed. The surviving SWAPO terrorists fled in confusion northwards. The SADF had clearly prevented the western units and $H Q$ s from penetrating further south than Cahama and had forced SWAPO units in that area into a definite defensive role.

Operation Askari confirmed the unmistakeable impression gained in Protea; viz the integration between the MPLA forces and SWAPO insurgents. This aspect was expressed in the close proximity of the two forces respective' $H Q$ s: and, most importantly, in the continous protection which SWAPO received from the Angolan Army, who deployed sophisticated Soviet weaponry under Cuban-Russian guidance. Marked examples of this process were the role of the T54 tanks and the AGS-17 grenade launcher; cf below.

\section{OPERATIONS MODULAR, HOOPER, PACKER AND DISPLACE}

In the August of 1987 South Africa despatched a force into south-eastern Angola in support of the anti-MPLA faction, UNITA. This force was originally intended mainly to halt an impending offensive by the Angolan Army (Fapla) against UNITA base areas. This was ultimately repelled on 3 October 1987 . when the 47th Brigade of Fapla was destroyed on the banks of the Lomba River. South Africa then resolved to extend these operations, with the object of pre-empting a renewed offensive in 1988. The underlying intention was to gain time for new political developments to take effect in the region. Accordingly, with the object of nullifying SWAPO/Fapla offensives, the South African forces drove the Fapla forces back to their launching points for future assaults and in the process created the most formidable minefield barrier in future years. The South African forces remained in south-eastern Angola for 12 months. Their strength never exceeded a real brigade of some 3000 men. Probably the most striking feature of this campaign was the dominant role assumed by the South African artillery; specifically, the role of the G5 gun-howitzer which, capable of a range of $40 \mathrm{~km}$, dominated the battlefield throughout the operations. The newly developed gun inflicted severe damage on Fapla, hampered their tactical and logistical movements; immobilized brigades preparatory to attack by South African mechanized forces and UNITA infantry: and rendered the important air base at Cuito Cuanavale totally inoperable.

The campaign thus formed a fitting climax to a decade characterized by the dominance of the artillery arm. ${ }^{3}$ The fighting also witnessed the first opera-

${ }^{3}$ Brig M S du Toit commented [conversation with S Monick: 14 March 1992] that the fighting was the very first occasion in the history of the $\mathrm{SADF}$ in which the issue was decided by artillery alone. 
tional use of the Olifant, a modernized version of the Centurion tank, as well as the G6. Moreover, several South African weapons underwent operational testing in this fighting; viz the Seeker RPV (a new anti-tank mis-sile), and the 'smart bomb' that de-stroyed the bridge at Cuito. Further, it is not widely known that the Mirages and Buccaneers of the SAAF flew sorties against Fapla brigades and their supply routes, incurring the loss of only two aircraft. These attacks were undertaken in the face of some of the most modern air defence equipment in service anywhere, and confronted by a large number of Mig 23s. The operations ecompassed by this campaign were designated Modular, Hooper, Packer and Displace.

\section{THE DIMENSIONS OF CONVENTIONAL WARFARE ENHANCED}

The operations detailed above exemplify the central features of SADF operations during the 1980s. First, and most importantly, the incursions into Angola necessarily highlighted a new and preponderant emphasis upon conventional warfare, pivoting upon mobile task forces. Whilst such forces included components directed towards searchand-destroy COIN missions, the armoured units also played a prominent role. Repeated references have been made above to the vital supporting role of mechanized infantry, deployed in Ratels.

The second major theme which emerges from a study of these raids is the frequent impossibility of differentiating between SWAPO - the focus of the South African incursions - and regular Angolan forces; the latter equipped and trained by Cuba and Soviet-Eastern bloc states. (Within this context, it should be borne in mind that the orientation and policy of the former Eastern bloc states - under Soviet inspiration and leadership - has obviously undergone a most drastic transformation concomitant upon the demise of the USSR and the resultant death of the Warsaw Pact. The 1980s were characterized by a powerful Imperialist, aggressive expansionist policy on the part of Cuba and the Soviet-Eastern bloc.
Both underpinned the Marxist MPLA during the Civil War and subsequent South African intervention on behalf of UNITA and other anti-MPLA factions; whilst, during the same decade, Soviet forces invaded and occupied Afghanistan. This expansionist policy obviously could not survive the collapse of its main protagonist, the USSR.)

Such active support and intervention on behalf of SWAPO necessarily implied the enhancement of the scale of the conflict, absorbing advanced weaponry and encompassing highly sophisticated anti-aircraft missile systems, armour and artillery.

One may detail certain of these weapons within the context of ground combat.

\section{ARTILLERY}

The $122 \mathrm{~mm}$ BM-21: The $122 \mathrm{~mm}$ 40tube BM-21 multiple rocket launcher was for many years the unsurpassed weapon of its type. It was first seen in public during a parade in Moscow in 1964. It is simply constructed and robust, firing an effective $78 \mathrm{~kg}$ rocket at a maximum range of 20500 metres. The BM-21 also fires a short rocket with a range of 11000 metres. In the service of the Soviet army it is mounted on the Ural-375 truck, an exceptionally resilient vehicle possessing good crosscountry capability. This variant is the most common export version in service with Fapla. In this form it weighs 11,5 tons. The truck has a road speed of 75 $\mathrm{km} / \mathrm{h}$, and a road range of $600 \mathrm{~km}$. The BM-21 served as the 'role model' for the South African $127 \mathrm{~mm}$ multiple rocket system (cf below) after a BM-21 had been captured in Angola.

$76 \mathrm{~mm}$ anti-tank gun: Manufactured in China, the $76 \mathrm{~mm}$ anti-tank gun Type 54 is a direct copy of the Soviet 76,2 $\mathrm{mm}$ Divisional Gun M1942 (ZIS-3). The $76,2 \mathrm{~mm}$ gun was introduced in 1942 and was the final variant in a long series of $76.2 \mathrm{~mm}$ field guns which can be traced back to the dawn of the 20th Century. It was subsequently developed for use in armoured fighting vehicles such as the T-34/76 medium tank (cf below) and the KV-l heavy tank; and, following the end of World War II, 
the PT-76 light amphibious tank. It also forms the main armament of the SU-76 self-propelled gun. The carriage of the $76.2 \mathrm{~mm}$ Divisional Gun M1942 (ZIS-3) is identical to that of the $57 \mathrm{~mm}$ anti-tank gun M1943 (ZIS-2) but the former has a shorter barrel with a double muzzle brake. The ZIS-3 fires the following fixed ammunition: APHE (UBR-354B) projectile, weighing $6,5 \mathrm{~kg}$, with a muzzle velocity of $655 \mathrm{~m} / \mathrm{sec}$ which will penetrate $69 \mathrm{~mm}$ of armour at a range of 1 000 metres; HE (UO-345 AM) projectile, weighing $6,2 \mathrm{~kg}$, with a muzzle velocity of $680 \mathrm{~m} / \mathrm{sec}$; HEAT (UBP-354 M) projectile weighing $4 \mathrm{~kg}$, with a muzzle velocity of $325 \mathrm{~m} / \mathrm{sec}$ which will penetrate $120 \mathrm{~mm}$ of armour at a range of 1000 metres; H VAP (UBR-354P) projectile, weighing $3,1 \mathrm{~kg}$, with a muzzle velocity of $965 \mathrm{~m} / \mathrm{sec}$, which will penetrate 92 $\mathrm{mm}$ of armour at a range of $1000 \mathrm{me}$ tres.

$82 \mathrm{~mm}$ B-10: The B-10 is a light, recoilless anti-tank gun, mounted on a small two-wheel carriage. Transported in a truck, it fires a $3,6 \mathrm{~kg}$ hollow charge round at $320 \mathrm{~m} / \mathrm{sec}$, with an effective range of 500 metres. This round can penetrate up to $200 \mathrm{~mm}$ of homogeneous steel. The gun has a rate of fire of six rounds per minute. As with all recoilless weapons, it is clearly visible as the result of the cloud of smoke and dust that it generates upon firing.

$130 \mathrm{~mm} \mathrm{M-46:} \mathrm{This} \mathrm{is} \mathrm{an} \mathrm{impressive}$ weapon that fires a $33,4 \mathrm{~kg}$ shell at a range of 27000 metres with accuracy. Until the advent of the South African G5, the only gun that offered a superior range was the American $175 \mathrm{~mm}$ $M-107$. The $M-46$ weighs 7,7 tons and has a split trail carriage. Possessing a rate of fire of six rounds per minute, it can be deployed in the direct fire and anti-tank roles, although its size does not ideally suit the weapon to these functions. The weapon was developed during the early 1950 s and was first seen in public during the 1954 May Day Parade. It replaced the $122 \mathrm{~mm}$ M 1931 (A-19) Field Gun. The M-46 is ballistically similar to the $130 \mathrm{~mm}$ guns used by the Soviet Navy.

ZU-23-4: The ZU-23-4 anti-aircraft gun is a self-propelled tracked quadruple 23 $\mathrm{mm}$ gun system that carries its own sur- veillance radar. The Gun Dish radar has a range of $20 \mathrm{~km}$. It is deployed with forward mechanized units together with SA-9 or SA-13 SAM (Suface-toAir Missile) systems. First encountered in the Middle East War of 1973, it is a very effective system, although its radar is prone to clutter when engaging low-flying aircraft. The ZU-23 is a clear weather system with no provision for radar fire control. The weapon fires two types of ammunition; the API-T (B2T) and HEI-T (MG 25). The API-T projectile weighs $0,189 \mathrm{~kg}$, has a muzzle velocity of $970 \mathrm{~m} / \mathrm{sec}$ and will penetrate $25 \mathrm{~mm}$ of armour at a range of 500 metres. The HEl-T shell weighs 0,19 $\mathrm{kg}$ and has a muzzle velocity of $970 \mathrm{~m} /$ sec. The gun was first introduced in the Soviet Army in the 1960s, on a scale of 24 per airborne division, 12 in the divisional artillery element and four in each of the three airborne rifle regiments.

$122 \mathrm{~mm}$ Howitzer D-30: This gun weighs only 3,15 tons and can be rapidly deployed in action. The weapon was introduced into service with the Soviet Army in the early 1960s, superseding the $122 \mathrm{~mm}$ Howitzer M1938 (M-30). The main improvements over the earlier weapons are increased range and the ability to quickly traverse the weapon through $360^{\circ}$, facilitated by the cruciform mount. An unusual feature of the $D-30$ is that the recoil system is mounted over the barrel. The D-30 fires the following variable charge, casetype, separate loading ammunition: $\mathrm{HE}$ projectile, weighing $21,8 \mathrm{~kg}$ with a muzzle velocity of $690 \mathrm{~m} / \mathrm{sec}$; HEAT projectile weighing $14,1 \mathrm{~kg}$ with a muzzle velocity of $740 \mathrm{~m} / \mathrm{sec}$ that will penetrate $460 \mathrm{~mm}$ of armour; chemical, smoke and illuminating rounds.

\section{ARMOUR}

T-34/85 medium tank: The first Soviet T34 production tanks were completed in June 1940, and the model was designated the T-34/76A. Towards the end of 1943 the T-34/85-1 was developed. This type consisted, basically, of the hull of the T-34 tank developed to the prototype stage in 1942-1943 and fitted with a turret developed from that fitted to the KV-85 tank mounting an $85 \mathrm{~mm}$ gun. Trials proved successful and pro- 
duction commenced late in 1943, the first production tanks being completed early in 1944. It has been estimated that, by the end of the War, 40 000 T34s had been produced. In 1947 the T-34/85-II was introduced. This model was essentially the same as the original T-34/85-I, but incorporating improvements in armour and fire controls, as well as a modified transmission. By the time that production was terminated, in 1964, a further 12000 tanks had been built.

Its armament originally consisted of the M-1943 (D5-T85) gun, but this was soon replaced by the M1944 (ZIS-S53) weapon. This gun is 54,6 calibres long and fires the same ammunition as the 85 $\mathrm{mm}$ field guns, $85 \mathrm{~mm}$ anti-aircraft guns (except the special anti-aircraft ammunition) and the SU-85 assault gun. Its practical rate of fire is 3-4 rounds per minute. The following types of ammunition are used: APHE with a $9,3 \mathrm{~kg}$ projectile, possessing a muzzle velocity of $792 \mathrm{~m} / \mathrm{sec}$, which will penetrate 102 $\mathrm{mm}$ of armour at a range of $1000 \mathrm{me}$ tres; HE with a $9,5 \mathrm{~kg}$ projectile, muzzle velocity of $792 \mathrm{~m} / \mathrm{sec}$ and a maximum range of 13300 metres at an elevation of $+25^{\circ}$; and HVAP with a $5 \mathrm{~kg}$ projectile, muzzle velocity of $1030 \mathrm{~m} / \mathrm{sec}$, which will penetrate $130 \mathrm{~mm}$ of armour at a range of 1000 metres. A $7,62 \mathrm{~mm}$ DTM machine gun is mounted coaxially to the right of the main armament and there is a similar weapon in the bow of the tank on the right side. The DTM is fired from a horizontal magazine with a capacity of 63 rounds. The tank's maximum speed is $55 \mathrm{~km} / \mathrm{h}$; its maximum range by road is $300 \mathrm{~km}$ and crosscountry $209 \mathrm{~km}$.

The T-34 is considered by many to be the finest all-round tank of World War II, and its appearance on the battle front was the principal factor motivating the development of the German Panther tank. Subsequent to the end of World War II the T-34 has seen combat in Korea, Vietnam, the Middle East and, of course. Angola. It is no longer in frontline service in any of the former Warsaw Pact countries but is still used in training and large quantities are held in reserve.

T-54/T-55: The T-55 and the earlier T-54 were the standard battle tanks of the
Soviet Army from 1954 until gradually displaced by the T-62 during the mid1960s. T-55s remain in service with second line units of the Soviet Army and were extensively used by the USSR's allies during the period subsequent to 1970. The T-55 is a tough, reliable tank that, manned by an efficient crew, remains a formidable threat, despite its 35 year vintage. It weighs 36 tons and is powered by a $520 \mathrm{hp}$ diesel engine. capable of a maximum speed of 50 $\mathrm{km} / \mathrm{h}$. Its road range is $300 \mathrm{~km}$. The T55 is armed with a $100 \mathrm{~mm}$ gun that fires an armour piercing round at a muzzle velocity of $900 \mathrm{~m} / \mathrm{sec}$. It can threaten even modern tanks from the sides, although no longer frontally. The normal ammunition load is 43 rounds. The armour is not proof against current western tanks and anti-tank weapons, but does nevertheless provide good protection against other counter measures on the battlefield.

\section{INFANTRY COMBAT VEHICLES}

BMP-1: The BMP-1 was the first true infantry combat vehicle in service, and is the Soviet counterpart of the Ratel. The BMP-1 (Bronevaya Maschina Piekhota) was developed in the early 1960 s as the successor the BTR-50P series of tracked armoured personnel carrier. The BMP-1 was publicly displayed for the first time during the 1967 November Parade in Red Square, Moscow. For a short period it was designated the $M-1967$, and subsequently the BMP-1. Its correct Soviet designation is now known to be the BMP-1.

The hull of the BMP-1 is made of all welded steel, providing the crew with protection against small arms fire and shell splinters. Compared with the Ratel, however, the BMP-1 is thinly armoured. However, according to American reports the armour provides complete protection from $12.7 \mathrm{~mm} \mathrm{AP/}$ API rounds over its frontal arc.

The main armament of the BMP-1 is a $73 \mathrm{~mm}$ model 2A20 smooth-bore, low pressure recoil gun, which weighs 115 $\mathrm{kg}$. This is fed from a 40-round magazine to the right rear of the gunner. The weapon fires a fixed fin-stabilized HEAT round with an initial velocity of $440 \mathrm{~m} / \mathrm{sec}$ which increases to $665 \mathrm{~m} /$ 
sec once the projectile has left the barrel and a rocket motor cuts in. The effective range is 1300 metres. According to American reports, the weapon is not effective in high winds, which deflect the path of the projectile. Maximum rate of fire is 8 rounds per minute. Positioned coaxially to the right of the main armament is a $7,62 \mathrm{~mm}$ PKT machine gun, which is fed from a continuous belt of 2 000 rounds honeycombed in an ammunition box positioned below the weapon. Mounted above the main armament is a launcher for a Sagger wire-guided anti-tank missile. One missile is carried in the ready to launch position; whilst a further two missiles are carried in the turret, which are loaded by means of a loading rail through a hatch in the forward part of the turret roof. Two additional missiles are contained within the hull. The vehicle is also armed with a single RPG-7 antitank grenade launcher and one BMP-1 in each platoon carries an SA-7 Grail SAM, which is launched by one of the infantrymen standing up in the troop compartment with one hatch open.

The crew numbers 11 (eight of whom are infantrymen and the remainer driver, gunner and commander). There are four firing ports on each side of the hull and four periscopes in the roof, each side for aiming. The forward firing port on each side is normally used for the $7,62 \mathrm{~mm}$ PKM machine gun and the remaining three either side for the AKMS $7,62 \mathrm{~mm}$ assault rifle (the Kalashnikov). Each PKM weapon is provided with 950 rounds of ammunition and each AKMS with 120 rounds.

The BMP-1 is a tracked vehicle and is fully amphibious, being propelled in the water by its tracks.

\section{ANTI-PERSONNEL WEAPONS}

AGS-17 Grenade Launcher: This weapon was first encountered by South African forces in the course of Operation Askari and exemplified the Angolan forces' deployment of sophisticated Soviet weaponry. The weapon had previously not been seen beyond the confines of the USSR. Several $30 \mathrm{~mm}$ AGS-17 grenade launchers were captured in the course of Askari. Up to the time of its appearance in southern Angola it had been issued only to Soviet military units. Codenamed Plamya ('Flame') the AGS-17 is a belt-fed grenade launcher possessing a capacity of 29 rounds, operated on a blowback system. Variants are reportedly mounted on vehicles and in helicopters. The weapon fires a $35 \mathrm{~g}$ grenade with an effective range of $800-1$ 200 metres, with a maximum of 1750 metres. This weapon was introduced in 1975, and hitherto had been issued to only some units of the Soviet Army.

\section{CONCLUDING OBSERVATIONS ON PART I}

The majority of these weapons were first encountered in the course of $\mathrm{Op}$ eration Savannah. It is necessary to bear in mind that, although the weaponry discussed above did not represent the very latest military technology (in the main dating from the 1950s and 1960s) it nevertheless heralded a scale of conventional warfare hitherto unprecedented in the experience of subSaharan Africa. At the point in time (1975) when they were first confronted by the MPLA, the South African army could only deploy medium and field artillery of World War II vintage; ie the $140 \mathrm{~mm}$ (5"5", later designated the $\mathrm{G} 2^{4}$ ) and $25 \mathrm{pr}$ respectively. In the Angolan War of 1975-1976 these weapons represented the South African artillery arm's anti-tank capability and were most seriously outranged and outgunned by the enemy's artillery. The South African ground forces possessed no armoured vehicles with which to confront the T-34 and T54/55 tanks until the 1980s; no armoured personnel carriers and no specific anti-tank weapon. Thus, the MPLA weapons systems form an interesting perspective, within which to assess the character and effectiveness of the South African response during the succeeding 15 years. The character of the opposition faced by the SADF during its subsequent strikes into Angola, and the necessary prerequisites demanded by

\footnotetext{
${ }^{4}$ As the terms G2,G4,G5 and G6 recur so frequently in this study, it is considered apposite at this point to elucidate their meaning. The G1 ('Gun 1) refers to the $25 \mathrm{pr}$; the G2 the $140 \mathrm{~mm}$ gun. The G4 is an imported, and simplified predecessor, of the G5 and the G6 is the G5 adapted to the role of a self-propelled gun. The G4 and G5 are both of $155 \mathrm{~mm}$ calibre.
} 
these operations - pivoting upon mobility and fire power (the latter especially deployed in an anti-tank role) - moti- vated and shaped the enormous technological advances which are discussed in Part II of this study.

\title{
THE FORGING OF A STRIKE FORCE (PART II)
}

\author{
The SADF is re-structured in the 1970 s
}

The year 1974 witnessed a vital transition in the formation structures of the South African army, exemplified in the creation of brigade groups.

The brigade system integrated artillery units into compact battle formations, embracing a variety of arms (ie infantry, armour, engineers, signals, maintenance), in marked contrast to the previous system, in which these arms were contained within loose organizational structures, effectively isolated from other arms. To cite but one example, 72 Brigade comprised the following units:

\author{
1 Bn Transvaal Scottish \\ South African Irish Regiment \\ Johannesburg Regiment \\ Transvaal Horse Artillery \\ 1 Light Horse Regiment \\ 12 Field Squadron, SAEC \\ 72 Signals Unit \\ 31 Field Workshop \\ 7 Maintenance Unit
}

The brigade group structures greatly facilitated centralization of control. and possessed the vital potential of being deployed as highly effective battle formations; as illustrated in Operation Savannah, and subsequent major exercises undertaken in 1978 and 1984 (ie Exercise Quicksilver and Exercise Thunder Chariot respectively). (It should be noted, however, that the brigade group infrastructure effected in 1974 also implied a far greater degree of centralization - vested in Brigade $H Q$ - with the corresponding dilu- tion of the decision making role formerly residing in the component regiments).

(The emergence of the brigade group, contained within a division, possessed distinct echoes of the organizational forms adopted by the UDF in World War II. Thus, 6 SA Armoured Division was initially formed on the basis of two brigades; 11 Armoured Brigade (comprising: Prince Alfred's Guard, Special Service Battalion, Pretoria Regiment and Kimberley Regiment) and 12 Motorized Brigade (consisting of: First City Regiment, Witwatersrand Rifles and Regiment De la Rey). In a similar manner, 5 SA Infantry Brigade (which was destroyed at the battle of Sidi Rezegh on 23 November 1941) consisted of: 1 SA Irish Regiment, 3 Transvaal Scottish and 2 Regiment Botha. However, the brigade structure instituted in 1974 differed in one major respect from its World War II precedent. For the latter was characterized by a sharp distinction between infantry and armour (as is evidenced from the example cited above); whilst, most importantly, artillery was organized on a divisional basis. (Thus, during the battle of Sidi Rezegh, 3 Field Regiment (SAA) (THA) together with sister field artillery regiments - were controlled by Divisional Headquarters). The pattern that emerged in 1974, which contained the artillery component within the brigade group, differed radically from the World War II precedent. (The advent of mechanized infantry during the 1980s effected a far closer integration of armour and infantry).) 
This re-structuring process was symptomatic of a far-reaching reorganization of the SADF, in which the Army's conventional forces were formed into two divisions; 7 SA Division' (comprising 71-73 Motorized Brigades) and 8 SA Armoured Division (consisting of $81 \mathrm{Ar}$ moured Brigade, 82 Mechanized Brigade and 84 Motorized Brigade). The HQs of the two divisions were established with effect from 1 August 1974; and they continue to constitute the basis of the organization of South Africa's modern conventional forces. Thus, the Citizen Force had eventually found a concrete organizational infrastructure following the uncertainties and experimentation of the 1960s.

It was certainly not coincidental that these new formation structures emerged at this particular point in time. April 1974 witnessed the Marxist inspired revolution within Portugal, powerfully spearheaded by the armed forces (which had been infiltrated by an extreme left-wing middle ranking officer corps, drawn from the middle classes, through the surrogate of conscription). The predictable result of their seizure of power in Portugal was the total capitulation to that country's former enemies in the Lusophone provinces of Angola and Mozambique. The barrier of the 'white south' had been totally and irrevocably broken, exposing South Africa's flanks and rendering a white Rhodesia extremely vulnerable (leading to her surrender within six years.) It is, indeed, this loss of the Portuguese African provinces that is the ultimate catalyst, shaping the military configuration of southern Africa for the succeeding 15 years; more specifically, the manner in which SWAPO's power was enormously enhanced by its access to the MPLA sanctuary of Angola. It is the binding and intimate relationship between SWAPO and its Angolan hosts which was a powerful motivating factor in the South African intervention in the Angolan civil war (Operation Savannah) and its succeeding cross-border raids spanning the decade 1978-1988.

\section{THE ARMAMENTS INDUSTRY²}

It should be borne in mind that the new strike force which executed the cross border raids during the 1980s had its weapons forged on the anvil of ARMSCOR; embodying that interaction between the armed forces and economic infrastructure, popularly referred to as the 'military-industrial complex' (a phrase that was widely adopted during the 1960s and 1970s, in relation to the Vietnam War). That relationship underpinned the technological revolution that shaped the SADF during the 1980s. ARMSCOR was the artery through which the wishes of the SADF was disseminated and ultimately assumed tangible form. This aspect will become manifest in the detailed discussion of the development of South Africa's new artillery systems during the 1980s (cf below).

ARMSCOR is placed directly under the Minister of Defence, parallel to the SADF, but is responsible to the Chief of the SADF for the economical and effective procurement of armaments. The management and formulation of ARMSCOR's policy is vested in a board of directors, appointed by the State President. Effective liaison with the SADF is ensured by the Defence Planning Committee comprising: the Chief of the SADF (Chairman); Chiefs of the Army, Air Force and Navy; the Chiefs of Staff Operations, Logistics and Finance: the Chairman and Chief Executive of ARMSCOR; and a representative from industry. The Committe's primary function is to ensure that the five year plan, the current budget and the procurement policy conform to the financial constraints imposed by the Cabinet. The current procurement procedure is initiated by the SADF formulating a requirement, followed by its approval by the Defence Planning Committee; whereupon ARMSCOR seeks to meet the requirement.

The major stimulus to the South African armaments industry derived from the

\footnotetext{
' The official designation, 7 Infantry Division, changed during the latter part of 1991, when it was altered to 7 SA Infantry Division. The writer is indebted to Cmdt R Ludeman for this information; telephonic conversation with S Monick: 17 February 1992.

2 This section of the study is derived from the following source:

Heitman, Helmoed-Römer. South African arms and armour. Cape Town: Struik, 1988, pp 14-16.
} 
United Nations arms embargo, imposed in 1962. The first major product of the industry, dating from 1964, was the assembly under licence - and later the manufacture - of the Panhard AML-60 and AML-90 armoured cars, by Sandock-Austral. Known as Elands, more than 1400 of these vehicles were manufactured in progressively improved variants, for the Army and for export. The year 1964 also witnessed the resumption of aircraft production.

The new programme was initiated by a trainer, a licence having been acquired to assemble the Aermacchi MB-326. The Atlas Aircraft Corporation was founded in 1965 and the first locally manufactured aircraft flew in 1967. Named Impala by the SAAF, this aircraft remained in production until the close of 1982.

Many other programmes were initiated in the mid-1960s; arguably the most interesting being the development of the air-to-air missile, a project that was initiated in 1966. The first successful interceptions were undertaken in 1972. The programme formed the basis for the weapons system designated the V3B (the 'Kukri' in its export form). The electronics industry also undertook its first foray into the sphere of military communications; introducing European equipment under licence, and then developing its products locally. An early success was the B-16 high frequency manpack which, in its export form known as the Racal Squadcal, achieved international sales of some 12000.

Thus, when the SADF embarked upon the offensive strategy which dates from 1978, the armaments industry was characterized by a secure technological-financial base, from which it could most efficiently respond to the testing and dynamic new challenges that were to emerge, in answer to the demands of the armed forces. Paralleling the development of new formation structures within the SADF (cf above), the armaments industry assumed new organizational forms. The various components of the governmental armaments production machine (eg Atlas) were streamlined into one organization - ARMSCOR - in 1976. Its function was defined as being 'to meet as effectively and economically as may be feasible the armaments requirements of the $R e$ public (of South Africa), as determined by the Minister, including armaments required for export and firearms, ammunition and pyrotechnical products required for supply to members of the public.'

ARMSCOR expanded rapidly, to emerge as one of the largest industrial groups in South Africa. In the late 1980s it possessed assets of R2 000 million, an annual turnover of some R1 500 million, and in excess of 20000 employees. A further 1000 sub-contractors furnished employment for an additional 90000 . The efforts of ARMSCOR have benefited South African industry generally, a process due not entirely to orders placed with the private sector; but also to the motivation to introduce (and in some instances develop) technology that might not otherwise have been available locally. Within this context, it should be noted that ARMSCOR contracts out to private industry whever feasible, with regard to both acquisition programmes and researchand-development projects. Only those items that cannot be accommodated economically by the private sector are retained as in-house programmes. Thus, private enterprise was responsible even for such major projects as the South African Navy's strike craft and the Ratel.

\section{MECHANIZED INFANTRY}

The Ratel (2): The key to mechanized infantry in the SADF is the Ratel Mechanized Infantry Combat Vehicle (MICV). There are, in actual fact, two variations of this vehicle; viz the Ratel 20 Infantry Fighting Vehicle (IFV) and the Ratel 60 IFV. These vehicles were developed as a range of tactical transport in order to rapidly convey the infantry into action whilst simultaneously providing them with armoured protection and fire support. Moreover, five further models were subsequently developed: viz the Ratel 90 Fire Support Vehicle (FSV), essentially a development of the armoured car; a Ratel Command Vehicle (the 12,7), in order to facilitate more effective control by the commander of a mechan- 
ized infantry platoon and battalion, especially within combat situations; a logistics vehicle $(8 \times 8)$, which is an eightwheeled variant designed to meet the logistical requirements of a mechanized unit which operates over extensive areas and periods of time; an 81 $\mathrm{mm}$ mortar carrier, and a Ratel mounting a ZT3 anti-tank missile system.

The initial design work on the Ratel commenced as early as 1968, conducted under the auspices of ARMSCOR, and the first prototype was completed in July 1974; to be followed by four pre-production vehicles, the first of which was produced in 1976. Thereafter, the Ratel went into full production.

The hull of the Ratel affords protection from small arms fire and shell splinters, and protection in the frontal arc against armour-piercing shells. With the exception of the logistical version (fitted with eight wheels) all models have six wheels. The crew of the combat vehicles - ie the Ratels 20 and 60 comprises 11 personnel: the driver, who sits in the front of the vehicle; the commander and main gunner who are seated on the left and right hand respectively of the two man turret; rear anti-aircraft gunner; section commander; and six infantryman. The command vehicle carries a crew of nine: the vehicle commander; main gunner; driver and six command post personnel. The Ratel 90 (FSV) carries a crew of 10, one fewer than the Ratel 20 and 60 - in order to enable 40 rounds of ammunition to be carried inside the hull. The crew comprises: the vehicle commander, driver, main gunner $(90 \mathrm{~mm}$ gun), rear anti-aircraft gunner, section commander and five infantrymen. The Ratel $8 \times 8$ Logistics Support Vehicle carries a crew of three (commander, gunner and driver), all seated in the fighting compartment in the front of the hull.

Standard equipment for the combat range of vehicles includes: a complete set of tools; spades, picks and axes; a tow bar and towing cables; a first aid kit; two petrol stoves; fire extinguishers; emergency spares; two 50 litre drinking water tanks; two external stowage compartments; radios, intercom and remote handset complete with 1000 metres of cable. There is an option also of night vision equipment with an air conditioning system. Further, the command vehicle carries: three radios; a tape recorder having a time injection facility; a civilian combined receiver and casette recorder in the hull; intecom system; public address system; pneumatic mast and map boards. The logistical support version has a carrying capacity of nine $1 \times 1,2 \times 1,2$ metre containers. They are able to convey various types of equipment and other materials (eg armour piercing ammunition, five-man tents, toilets and showers, a refrigerator and freezer, and 800 litres of water.) In the hull, integral fuel tanks contain 2000 litres of fuel with a hydraulically powered pump capable of filling the bunker tanks with an external supply; or fill two vehicles simultaeously on each side of the bunker and also pump fuel from one external bunker to another. In the event of a power failure hand pumps are provided. Standard equipment includes tanks for fresh water, a generator, three spare wheels, spare parts and tools.

With regard to speed, the Ratels 20,60 and 90 can attain a maximum speed of $105 \mathrm{kph}$ on the open road; they have a maximum fuel capacity of 430 litres and a maximum range of 1000 $\mathrm{km}$ on road and 14 hours travelling cross-country. The Ratel $8 \times 8$ is capable of a maximum speed of $86 \mathrm{kph}$ on the open road, a fuel capacity of 560 litres and a maximum range of $760 \mathrm{~km}$ on road or 14 hours travelling cross country.

Practical experience of the vehicle in South West Africa and Angola has generated modifications in the family of Ratels (eg improvements in power trains, suspensions, 'run-flat' tyres and the use of more than two axles), greatly enhancing their cross country mobility and significantly reducing their vulnerability. The MICV, of which the Ratel is an illustration highly esteemed by overseas authorities, combines the major facets of tracked infantry fighting vehicles (IFVs) and wheeled armoured personnel carriers (APCs). The Ratel is equipped with the same major armament as that borne by tracked IFVs, whilst it is fitted with vision blocks 
and firing ports for its complement of infantrymen, thus rendering it almost as effective as a tracked IFV. Moreover, in the terrain that forms the geographical context of the Ratel's operations, the superior mobility and lightness render it an improved vehicle with regard to the majority of tracked IFVs. Thus, the weapons capability and infantry support potential of the tracked IFV is combined with the mobility and travelling capacity of the APC.

The armament varies according to the particular model.

Ratel 20IFV: The first version within the series - the Ratel 2OIFV - is armed with a $20 \mathrm{~mm}$ (F2) cannon (M693) which is mounted on a small turret, together with a co-axially mounted $7,62 \mathrm{~mm}$ machine gun to the left and a further 7,62 $\mathrm{mm}$ machine gun mounted on the turret roof. The $20 \mathrm{~mm}$ cannon is capable of firing three types of ammunition: designed for anti-aircraft defence; armour piercing shells; high explosive $(H E)$; and practice rounds.

Ratel 60IFV: The Ratel $60 \mathrm{IFV}$ is equipped with a two man turret armed with a $60 \mathrm{~mm}$ mortar and a co-axially mounted $7,62 \mathrm{~mm}$ machine gun with an additional $7,62 \mathrm{~mm}$ anti-aircraft machine gun at the rear of the vehicle on the right side. The mortar is breech loaded, and capable of firing smoke, $\mathrm{HE}$ and illuminating bombs to a maximum range of 1500 metres. A typical ammunition load would consist of 38-45 $\mathrm{HE}$ bombs, three smoke and three illuminating bombs.

Ratel 90FSV: The Ratel 90FSV is equipped with a $90 \mathrm{~mm}$ semi-automatic quick firing gun mounted on a twoman turret. As in the case of the Ratel 20 and 60 models, a $7,62 \mathrm{~mm}$ machine gun is mounted co-axially on the turret to its left. The $90 \mathrm{~mm}$ gun fires HEAT, HE and practice rounds. Further, a 12,7 $\mathrm{mm}$ M2 HB machine gun can be mounted over the $90 \mathrm{~mm}$ gun for training purposes.

Ratel Command vehicle: The Ratel command vehicle is equipped with a $12,7 \mathrm{~mm} \mathrm{M} 2 \mathrm{HB}$ machine gun and also two $7,62 \mathrm{~mm}$ anti-aircraft machine guns: one mounted above the turret and the other at the rear left. Also mounted on either side, towards the rear of the turret, is a bank of two 81 $\mathrm{mm}$ electrically operated smoke dischargers, which can be operated by the commander or gunner.

Logistics vehicle: The $8 \times 8$ logistics vehicle is equipped with one $12,7 \mathrm{~mm}$ anti aircraft machine gun on the front of the vehicle. (However, it should be noted that this model is not being extensively produced).

Ratel-81: The Ratel-81 is essentially a turretless Ratel fitted with an $81 \mathrm{~mm}$ mortar in the fighting compartment, with the re-designed commander's cupola situated between the compartment and the driver. The mortar is mounted on a turntable with a $360^{\circ}$ traverse. This variant of the Ratel allows the mortar teams to enter and withdraw from an action far more rapidly than was possible with ground mortars. The Ratel-81 also affords a good measure of armoured protection, although in action the crew are obviously disadvantaged by the need to open the top of the fighting compartment in order to fire the mortar. When necesssary the mortar can be dismounted and fired from the ground. The main armament consists of one 81 $\mathrm{mm}$ front-loading mortar. The ammunition carried consists of 148 mortar bombs. The secondary ammunition comprises two $7.62 \mathrm{~mm}$ machine guns; one mounted on the commander's cupola and the other on a ring mount at the rear of the vehicle for close-range and anti-aircraft defence. The ammunition for these machine guns consists of 1200 rounds. In addition, there are four $81 \mathrm{~mm}$ smoke grenade launchers. There is one firing port in each hull side and side door. The crew numbers five and the vehicle weighs 18,5 tons combat loaded.

Ratel mounting ZT3 Swift anti-tank missile: ${ }^{3}$ The latest variant of the Ratel mounts the Swift anti-tank missile: a new laser guided system developed by Kentron, the subsidiary of ARMSCOR responsible for guided weapons. Oper- 
ation Savannah and the subsequent incursions into Angola, discussed in Part I of this study, highlighted the urgent need for an effective anti-tank system. One recalls the destruction of a Ratel by tank shells in the action at Cuvelai, during the course of Operation Askari. Operation Savannah witnessed the extensive deployment of the T-34 tank, whilst subsequent operations encountered the widespread use of the T-54 and $\mathrm{T}-55$ tanks.

The ZT3 operates on the principle of semi-automatic command-to-line-ofsight (SACLOS). The weapon features a unique laser command link which eliminates the need for guidance wires and facilitates an extended range. The missile is of $127 \mathrm{~mm}$ calibre. It consists of a hollow-charge warhead, a flight motor and a guidance unit incorporating a laser receiver and an infra red source. It has a range in excess of 4000 metres and is capable of penetrating $650 \mathrm{~mm}$ of armoured steel.

The operator selects a target, using a telescope, and this establishes the line of sight from the system to the target. Following launch the angular deviation between the missile and the line of sight is measured by the goniometer with the aid of a pulsed infra red source in the tail of the missile. The angular deviation, or error angle information, is processed by the guidance unit. Corrective commands produced by the guidance unit are encoded and transmitted to the missile via the laser transmitter, in the form of pulsed laser commands. The laser receiver in the tail of the missile detects and encodes the pulsed laser commands and feeds the information to the inboard flight control unit, which transforms it into servo commands. The servos are connected to the control fins at the rear of the missile. Commands from the flight control unit cause the control fins to manoeuvre the missile into the line of sight. The missile follows the line of sight until it strikes the target, and the hollow charge warhead ensures that the target is effectively eliminated. The rate of fire is estimated to be two missiles per minute.

Although initially developed for the Ratel, the ZT3 may be fired from alternative platforms such as a tripod or helicopter (in the latter instance from South Africa's new Rooivalk (Kestrel) attack helicopter. This greatly enhances the operational flexibility of the system, and renders it adaptable to the client's needs.

The ZT3 system is supported by a well developed logistical apparatus. The missile itself is sealed in its launch tube container and requires no maintenance. The units installed in the Ratel turret can be tested - and faulty units replaced - at first line with the aid of a self-contained microprocessor controlled test unit. Kentron can also supply a full training package.

The weapon was first revealed to the public at the Pretoria Show in August 1990. International defence media have speculated that the ZT3 was successfully deployed against tanks during the final phase of South Africa's military intervention in Angola.

The combination of the ZT3 Swift system with the Ratel points to two interesting characteristics of South African weapons systems during the 1980s. The first is the integration of diverse arms. Thus, the combination of the ZT3 with the Ratel embodies the fusion of mechanized infantry and anti-tank systems. In this respect, it parallels the interaction between artillery and armoured infantry, commented upon below. Secondly, it has been stated that the SovietEastern bloc weaponry deployed in Angola during the period 1975-1990 forms a perspective within which to gauge the success of the South African response. The ZT3 mounted on the Ratel counterpoints the BMP-1 Soviet armoured personnel carrier; the ZT3 representing a far more sophisticated and efficient version of the Sagger missile. The new anti-tank missile and the mechanized infantry fighting vehicle developed by ARMSCOR encapsulates the technological advances effected by the SADF and armaments industry in relation to its former adversaries.

\section{The challenge of the armoured infantry role}

The Ratel's capabilities fulfil the demands which the MICV must meet, in order to successfully implement me- 
chanized infantry operations; those demands being:

- Mobility, in order to keep pace with the tanks;

- Long range fire capable of suppressing enemy anti-tank weapons and dismounted infantry:

\section{- A stabilized turret to provide this} same capability whilst in motion.

- A high volume of lethal fire to support dismounted infantry and to disrupt enemy attacks:

\section{- Superior radio communications;}

\section{- An anti-tank capability organic to} the vehicle.

The Ratel was first deployed in a combat role in the course of Operation Reindeer (1978), in which it was used by 61 Mechanized Infantry Battalion. The first Citizen Force unit to be converted to mechanized infantry was 1 Regiment Northern Transvaal. In Paratus (August 1984) it is stated ( $p$ 47) that this unit was converted to a mechanized infantry battalion in May 1975. However, as this predates the first production model, the statement may be construed to mean that May 1975 marks the date on which the regiment commenced training and exercises in the principles of mechanized warfare.

The Ratel has obviously exercised the most profound impact upon the infantry, which henceforth becomes both armoured and mounted. This mounted fighting capability has tremendously enhanced its mobility; a central factor in the huge expanses of territory that have to be traversed by South African infantry. Equally, the firepower of the infantry has escalated to an enormous degree. The vulnerability of the infantry is also dramatically decreased. The Ratel's speed, agility and protective function drastically reduces the time during which the infantry component is exposed in the course of protracted assaults over open ground, and the Ratel 90 is able to provide excellent fire support for dismounted infantry. This dilution of vulnerability is an especially important asset for the infantry within the context of the modern combat environment, in which it is exposed to every weapon on the battlefield; ranging from small arms and anti-personnel mines to heavy artillery and air strikes. Thus, if infantry units are to survive and accomplish their mission they must use all available means to reduce their vulnerability. It is apparent, therefore, that mobility, firepower and armoured protection are the inherent characteristics of mechanized infantry and interact to create a totally new dimension in the infantryman's role, in which he is fully integrated into the armoured and artillery forces. It is, of course, apparent from the foregoing military scenario within which mechanized infantry operates that this new conception of the infantry role is far removed from the COIN function and orientated towards the foot soldier's contribution to an extremely mobile conventional warfare environment. The character of the enemy envisaged is very different from the insurgent which COIN operations are designed to neutralize, and is conceived in terms of heavy conventional armament. There can be little doubt that the experience of Angola was a key factor in the development of the Ratel.

The new role of the mechanized infantry arm is lucidly and succinctly analyzed by Col Z B Bradford in an article entitled Motorised infantry on the modern armoured battlefield. Col Bradford writes (3):

'Mechanized infantry permits the effective employment of the combined arms team on the armoured battlefield, a difficult role which demands exceptional ability on the part of the Infantry leaders who must learn to think in terms of "mounted warfare". This does not mean that infantrymen alway stay mounted on their vehicles or that they merely "ride" carriers and then dismount to fight. Mechanized infantry is an integral and permanent part of the tank infantry team...

Mechanized infantry has two major roles in mounted warfare: to facilitate the forward employment of the 
combined arms team; and to move and quickly occupy positions which will deny the enemy freedom to conduct particular operations or force him into areas of our choosing.

To facilitate further employment, infantry must clear obstacles which block or inhibit armour; suppress anti-tank weapons - either on the move or from overwatch; and precede armour as required by enemy actions or terrain restrictions.

The commander's use of the infantry to quickly occupy positions allows him to "structure" the battlefield, to give shape to a defense or other operations in a manner which tanks alone cannot effect. This role also translates into some key tasks: moving rapidly under fire; quickly taking up defensive (blocking) positions against both infantry and armour assault; occupying delay positions; inflicting various degrees of destruction on advancing enemy as required; and quickly disengaging to move elsewhere.

In conducting these tasks, the infantry maximises its mobility and armour protection and always operates as part of the combined arms team.'

Col Bradford emphasizes the point that speed of response is the essence of the successful mechanized infantry operation (3):

\begin{abstract}
'How fast the team reacts to enemy contact will usually determine the success or failure of a mission. The report of enemy contact should trigger actions and decisions from squad through company level almost simultaneously. The lead element (squad/platoon) must immediately deploy, return fire, report and call for fire support.
\end{abstract}

In order to expose the strength and disposition of the enemy force, the lead element develops the situation by fire and manoeuvre. The platoon leader and team commander must immediately suppress enemy weapons... and, if necessary, with indirect fire support.

The team commander must decide whether the enemy position should be attacked or bypassed, or whether the lead platoon must reconnoitre and probe further to learn more about enemy strength and positions."

The traditional role of artillery - that of supporting infantry - assumes a new dimension within the context of mechanized infantry, orientated towards mobility. A manifestation of this process is that the OC, Fire Support Officer, the Battery Commanders and Observation Post Officers now accompany the infantry in Ratels. Such a concept is perfectly tailored to the development of the G-6.

\section{SOUTH AFRICAN ARTILLERY SYSTEMS OF THE $1980 \mathrm{~s}^{4}$}

It is apparent from the foregoing section that, in so far as Operation Savannah dramatically exposed the total obsolescence of South African artillery systems, it exercised an enormous impact upon South African military thought. The role of the Angolan war in effecting the startling modernization of South African artillery systems is succinctly stated in the work Ultima Ratio Regum; more specifically, in the chapter entitled New South African artillery systems in the eighties. The authors write ${ }^{5}$ :

'In 1984 the respected international military journalist, lan $\vee$ Hogg, wrote in Jane's Military Review that the Republic of South Africa had "not only caught up with but had, in many areas, surpassed the rest of the world in armaments development."

The single most important area of armaments development in which the RSA had achieved an undisputed

\footnotetext{
${ }^{4}$ This section of Part II is derived from the following source, unless where otherwise stated:

Dorning, W A \& Lillie, A C. New South African artillery systems in the eighties. in Nöthling, Cmdt C J (ed). Ultima Ration Regum...(Artillery history of South Africa). Pretoria. SADF. Military Information Bureau, 1987, pp 395-405.

${ }^{5}$ Dorning, W A \& Lillie, A C. New South African artillery systems in the eighties. in Nöthling, Cmdt C J (ed). Ultima Ratio Regum...(Artillery history of South Africa). Pretoria: SADF. Military Information Bureau, 1987,
} 
lead by the mid-eighties was unquestionably that of field artillery. With the development of the G-5 $155 \mathrm{~mm}$ gun-howitzer, the G-6 selfpropelled gun and the $127 \mathrm{~mm}$ MRL "Valkiri" artillery rocket system, the SA Defence Force today possesses arguably the most advanced and effective field artillery system in the world, the super-powers not excepted. ${ }^{\circ}$

The excellence and modernity of contemporary South African artillery sometimes tends to obscure the fact that this was not always the case. Indeed, as late as the mid-seventies the South African Field Artillery equipment and systems were obsolete even by African standards. When the armed forces of South Africa became involved in large scale operations in Angola in 1975-76, its field artillery consisted entirely of Second World War vintage ex-British 25-pounder $(87,6-\mathrm{mm})$ and 5,5 -in (140-mm) gun howitzers.

The 25-pounder and "five-fives" were badly outranged by the Soviet weapons in the hands of the Cuban and Angolan forces during the Angolan conflict. In particular, the South Africans discovered that they had no answer to the long range of the 122-mm "Stalin Organ" multiple rocket launcher (BM 21 type).

As it happened, the deficiencies in the South African Field Artillery which had been exposed during the Angolan War acted as a long overdue catalyst to the subsequent development and modernization of the field artillery.'

The above quoted extract prefigures the approach and pattern adopted in this section, in two important respects. The first is the manner in which Operation Savannah exposed the dangerous obsolescence of the SADF's field artillery. The second is the dramatic and rapid response to such a situation.

\section{THE G4}

tracted an enormous amount of attention and publicity. The G4 has received extremely little in comparison. Nevertheless, it merits study in the scope of this article in so far as it was the predecessor of the G5. In a major respect it differs radically from its successor, in so far as it was an imported gun, its source being undisclosed. However, it occupies an important role in this study, in so far as its introduction necessarily involved an enormous transition in the technological aspects of gunnery. It was issued to the Transvaal Horse Artillery in 1980 and, at that point in time, represented the most advanced gun in service with the South African artillery corps. The $\mathrm{G} 4$ thus occupies an important role in the history of that regiment. The weapon is a simplified version of the G5, being a 155 $\mathrm{mm}$ gun howitzer. The specifications of the gun are as follows:

Crew: 8

Mass: 9,2 tonnes

Dimensions (in travelling configuration):

length $-7,5 \mathrm{~m}$; width $-2,58 \mathrm{~m}$; height $-2 \mathrm{~m}$.

Mobility by means of 10 tonne gun tractor; maximum speed $100 \mathrm{~km} / \mathrm{h}$. Air transportable in Hercules and Transall aircraft.

Elevation: $-5^{\circ}$ to $+52^{\circ}$

Traverse: $84^{\circ}$

Maximum range: $25500 \mathrm{~m}$.

Muzzle velocity: $820 \mathrm{~m} / \mathrm{s}$ maximum (HE projectile).

Traverse: 84 degrees.

Rate of fire: 4 rounds per minute; 2 rounds/min sustained.

Ammunition:

High Explosive (HE) $-43,7 \mathrm{~kg}$

White phosphorus - 43,7 kg

The G5 has, for obvious reasons, at-

${ }^{6}$ The use of the term 'field artillery' is questionable within this context. The G-5 and G- 6 conform more closely to the role of medium artillery; and, indeed, the distinction between field and medium artillery has been attenuated to the point of non-existence by these weapons. 
The $G 4$ is a 39 calibre-length (as opposed to the 45 calibre-length of the G5/G6) gun-howitzer), which was purchased in limited numbers as interim ordnance following the experiences of Operation Savannah. Essentially, it is a conventional gun with a split trail. It will be noted that the type $(155 \mathrm{~mm}$ ) prime mover (the 10-tonne gun tractor) is identical to that of the G5; whilst the rate of fire is very similar to the latter gun. Thus, whilst the $G 4$ lacks the range of the $\mathrm{G} 5$ (25 $500 \mathrm{~m}$ with regard to the former, as opposed to a maximum range of $39000 \mathrm{~m}$ in the latter case) the G4 complements the artillery system in terms of range. Whilst the G6's range of fire is identical to that of the G5, the Valkiri rocket system is capable of ranges of between 8000 and 22000 metres, and the $120 \mathrm{~mm}$ mortar (M5) (approximating to light artillery) ranged at $6250 \mathrm{~m}$. The $\mathrm{G} 4$ thus facilitates an intermediate range of fire between, at one extreme, the $120 \mathrm{~mm}$ mortar and, at the other, the G5/G6.

To reiterate, the introduction of the $G 4$ involved a quantum leap in technological terms, as it absorbed the Transvaal Horse Artillery into the 155 $\mathrm{mm}$ ballistics system. An immediate consequence of this far reaching transition was the total obsolescence of the former system of yards and metres and the (in some instances traumatic) reorientation from an artillery board to a computer. This dramatic development was personified in the personal experience of Cmdt Rimmer, who commanded the Transvaal Horse Artillery during the period 1985-1989 and had served with that unit since 1976. He emphatically agreed that a vast distance in technological terms separates the $25 \mathrm{pr}$ and $140 \mathrm{~mm}$ guns from the G4. He remarked (4) that, when he enlisted in the artillery corps in 1974, he was trained on the $25 \mathrm{pr}$ and $140 \mathrm{~mm}$ guns. The weapons embodied the British technology of World War II vintage; prescribing precisely the same drills and tactics prevailing in the Second World War. The $155 \mathrm{~mm}$ ballistics system involved the total obsolescence of the traditional artillery board, in which the range arm and bearing arc was marked out in yards and degrees. The new system involved calculations based on 6400 mils within a circle (un- like the Soviet artillery system, which pivots upon 6000 mils within a circle).

The source of the $G 4$, to reiterate, is undisclosed. Cmdt Rimmer is of the opinion (5) that it was designed for deployment in a sophisticated First World developed environment (eg Europe) where the guns would be re-deployed from one position to another through means of the German autobahns, for example. Cmdt Rimmer stated (6) that, once emplaced, the $G 4$ was a superb gun, possessing the best range available at that time. It was also extremely accurate. However, the weapon was gravely disadvantaged in operational terms as it was not orientated to the African terrain. The gun's major problem was thus mobility. Certainly, it was extremely mobile when transported on modern highways; but it proved to be most vulnerable when towed behind the gun tractor through dense bush, in which the fragile sight brackets could be wrenched off by a thorn tree. Lacking the hydraulic support of the $G 5$ and weighing some 10 tons (as opposed to the nine tons of the G2), the G4 was a most difficult gun to bring into action. Whilst two gunners can execute this operation in the case of the $G 5$, the $G 4$ requires a full gun crew, who must participate in arduous team work. Moreover, the G4 is certainly not a gun which readily lends itself to air transport.

The G4 was never used operationally by the THA. The gun was, in actual fact, only deployed in an operational role in November 1983, at the outset of Operation Askari. The guns were removed from the hangars at Alrode and flown to the border. At that point in time. when the G5 was not yet available, the $G 4$ could not be surpassed in terms of range and firepower. The latter weapon was manned by national servicemen and a battery (ie eight guns) were deployed. Of these, seven were returned to the THA; one of the gun tractors receiving a direct hit and having to be scrapped. The remaining G4s were in a severe state of disrepair, having been subjected to considerable fire. It was then realized that, although the weapon clearly possessed the desired range and firepower, it was most gravely disadvantaged in the op- 
erational theatre. The brackets of the guns' sights had been ripped off and the gun tractors could not keep pace with the other forces, not being sufficiently powerful to tow the G4. The same tractors had served as prime movers of the $G 2$, but the subtle difference in weight between the guns drastically affected the pulling capability of the gun tractor and thus the mobility of the $\mathrm{G} 4$.

The capabilities of the $G 4$ - in both its positive and negative aspects - clearly emerged in the course of Exercise Thunder Chariot (1984). It occupied approximately one hour to move the $\mathrm{G} 4$ some $20 \mathrm{~km}$. The ammunition was not stored in the trail legs (as in the case of the G5). The entire volume of ammunition for the $G 4$ was stored in the gun tractor, due to the risk of a considerable proportion being lost owing to its not being properly strapped on. However, once the weapon had been deployed, the THA out-gunned the national service battery, equipped with the G5, which also participated in Thunder Chariot. The G4's response times and accuracy could outmatch the G5, although the former was obviously outranged.

The $G 4$ was subsequently withdrawn from service with the THA (being issued to Regiment Potchefstroomse Universiteit), and the former has reverted to the $G 2$.

\section{THE G-57}

\section{Development}

Within a mere matter of months from the end of the Angolan conflict, the South African Armaments Corporation (ARMSCOR) was tasked with the project of developing a modern sophisticated artillery system for the SADF. A major problem existed, however, in relation to the procurement of the necessary technology. This was the international arms boycott, formally directed against the Republic for over a decade, and soon to attain concrete substance in the form of a mandatory UN-supported arms boycott (established in November 1977). The difficulty was resolved by a Canadian concern; the Space Research Corporation of Quebec (SRC-Q). SRC-Q had, for several years, been conducting research with the object of achieving significantly greater artillery ranges than were possible at the time. This experimentation pivoted upon both long barrels and ammunition designated ERFB (Extended Full Range Bore). These two factors conjoined in producing a weapons system possessing a maximum range in excess of $30000 \mathrm{~m}$. This represented a range that was considerably superior to that of NATO gun-howitzers.

ARMSCOR acquired a minority shareholding in the Canadian company, and thence collaborated in the development of an artillery system specifically orientated towards South African requirements. Through the medium of SRC-Q, the Canadian company acting as a conduit, ARMSCOR contacted PRB (a Belgian ammuntion firm) and thereby gained access to the concept of 'base bleed'. When combined with ERFB technology, base bleed enabled guns to achieve ranges which, up to that point, had been impossible to achieve. Base bleed ammunition involved a small amount of powder being burnt at the base of the projectile as it leaves the barrel. This reduces the vacuum created by a projectile as it leaves the firing chamber, thereby greatly enhancing its range. The $155-\mathrm{mm}$ gun thus developed was internationally marketed by SRC- $Q$ under the designation of the GC45. ARMSCOR continued with the further development of the gun. Two guns were manufactured by SRC in 1979 and, following trials in both Canada and on the island of Antigua, manufacture was transferred to South Africa, where the two guns served as prototypes for series production. The South African association with SRC-Q was subsequently discovered and resulted in the imprisonment of the Company's president, Dr Gerald Bull (who refused South African offers of sanctuary and protection) on charges of contravening the UN arms embargo.

Dr Bull was subsequently murdered in March 1990; it is commonly thought by 
agents of a power which strongly disapproved of some of his clients. Dr Bull's enormous impact upon weapons technology - and its fatal consequences for him -are succinctly explored in an article which appeared in the Sunday Times (South Africa) (dated 1 April 1990), by Jeremy Brooks and Patricia Cheney:

'Space-gun secret of murdered G5 boffin

A brilliant scientist, murdered in his Brussels flat last week was working on a large calibre "space cannon" for Iraq using the technology behind SA's famed $G 5$ field gun. The science-fiction weapon is designed to launch nuclear, chemical or conventional warheads into orbit - or to lob them hundreds of kilometres across borders.

Defence and intelligence analysts in Europe and Canada suggested this week that Dr Gerald "Jerry" Bull, was killed to prevent Iraq gaining an edge over its Middle Eastern neighbours. Speculation was rife that Israel's secret service Mossad was behind the professional assassination.

But US State Department officials in Washington hinted that Iran may have chosen to strike in the wake of antiIraqi feeling following the execution of London-based journalist and alleged spy Farzad Bazoft.

A British expert on terrorism said the killers - who fired two $7,65 \mathrm{~mm}$ bullets into the back of Dr Bull's head and left his wallet stuffed with £53 000 untouched could have come from any one of several countries.

\section{DUMMIES}

"Syria, Jordan and Iran all have an interest in preventing Iraq gaining a strategic advantage in the arms race.

"Any of them, or Israel, would have a prime motive", said Professor Ray Wilkinson, of the Institute for the Study of International Conflict and Terrorism.

Dr Bull is known to have visited Iraq regularly in the past few years...

It was Dr Bull's research in the Sixties into a $60 \mathrm{~cm}, 40 \mathrm{~cm}$-bore "gun" to launch weather satellites into space that led to the genesis of the South African $155 \mathrm{~mm} \mathrm{G} 5$ field gun.

The sophisticated weapons system is acknowledged as the best of its kind in the world, as is the motorised G6 version. Both can fire with deadly computer-controlled precision at targets more than $40 \mathrm{~km}$ away.

Dr Bull's initial work at a test range straddling the US-Canadian border was designed to replace rocket-launched weather satellites.

He boasted he could fire projectles horizontally into Mexico - or $2000 \mathrm{~km}$ vertically into the atmosphere.

The Canadian government, which was sponsoring the project jointly with the US, became worried about the military potential and soon withdrew.

The Pentagon was curious - Dr Bull's invention could be vastly cheaper than missile-launched warheads.

But even they baulked at the nine-figure sums when Dr Bull asked for funding to go into full production.

The scientist later claimed that missile manufacturers, who stood to lose heavily if his ideas were accepted. pressured Washington into withdrawing support.

But a spin-off of the ballistics research into the space gun was an improved, extended-range $155 \mathrm{~mm}$ artillery system.

Dr Bull had invented a shell which had no equal in its range, destructive power and accuracy.

With it came a howitzer conversion kit which would enable normal artillery to take the heavier and more powerful projectile.

\section{DEAL}

...Dr Bull's credit with a Pennsylvania bank was stretched to the limit when he broke the arms boycott and began dealing with South Africa. 
But he was eventually able to pay off an overdraft of more than R26,5- million in a deal that pushed his company well into the black...

But his genius - at 22 he was the youngest graduate ever to get a doctorate from Toronto University - left no room for cost control. He was totally absored in his research while his company plunged into the red.

The South African deal came at a price - his conviction in 1980 for breaking the US arms embargo against South Africa and a six-month jail term. His death last week marked the 10th anniversary of his imprisonment, almost to the day.

British arms specialist $\mathrm{Mr}$ James Adams claimed in 1984 that South Africa, through ARMSCOR and a Dutch-based front company, financially rescued $\mathrm{Dr}$ Bull's Space Research Corporation. They thus managed to control the patent on the technology leading to the G5.

Following his imprisonment in 1980, $\mathrm{Dr}$ Bull disbanded the Space Research Corporation but set up a new company, Space Research International, with its headquarters in Brussels.

There are strong indications that he maintained contacts with the Pentagon, the CIA and the US Defence industry.

In the seventies, SRC - which straddled the US-Canadian border - set up its owns customs site and customs officials who tried to make on-site inspections of shipments were, according to one account, ordered by their superiors to stay off the company's property.

One official said at the time: "We all assumed that SRC was doing a lot of hush-hush military work at the Pentagon..."

\section{TRIAL}

In Norway, an arms watchdog body claimed Dr Bull was heavily involved in helping Iraq to buy $G 5$ and $G 6$ arms and ammunition.

An Austrian firm, Woest-Alpine, goes on trial next month charged with selling the guns to both Iran and Iraq - but it is alleged that the weaponry was originally supplied by SRC.

ARMSCOR has consistently declined to comment on its reported ties with Dr Bull and SRC. '

Whilst the necessary technology and trial models had been thus acquired, the quite distinct problems of actually achieving series production within a relatively limited period remained, in the light of the fact that the Republic possessed neither the facilities nor the experience for the mass production of artillery pieces. Nevertheless, the problem was overcome by the close co-operation between the SADF, private industry, ARMSCOR and its affiliates; a co-operation which bore fruit in the delivery of four $155 \mathrm{~mm}$ G-5 evaluation models to the SADF in 1981. The following year the series production of the $G$ 5 commenced; preceded by a period of intensive testing and continuous feed-back in regard to the performance of the artillery system under operational conditions.

To quote the words of one source ${ }^{8}$ :

'The nett effect of the remarkable story behind the development of the G-5 in South Africa is that today the Republic possesses some of the world's most modern gun and ammunition facilities. The Republic has, within the space of a few short years, acquired the capability of manufacturing the high quality steel required for gun barrels and projectiles from its own iron ore resources, and is in fact now completely self-sufficient as far as the production of the complete $G-5$ system is concerned.'

The South African development of the G-5 effected far reaching repercussions upon the artillery systems of those nations not included within NATO. For the Republic was capable of marketing to Third World countries a weapon which exceeded the capabilities of

${ }^{8}$ Ibid item (4) above. 
NATO artillery. The point is made in an article contained in the publication Military Technology (1/83), entitled G-5 \& G-6: South Africa does it (almost) by itself; an extract from which reads as follows:

$\because$...because South Africa was the only country to immediately grasp the potential offered by the SRC-Q's researches, there is now a situation in which artillery weapons are being produced - and marketed to the Third World - whose operational performace far exceed those of similar weapons fielded by the most advanced NATO and Warsaw Pact armies. Just to give one example, Thailand (which has two batteries of GC45 in service, having ordered the weapons from SRC- $Q$ before the firm closed down) is now better equipped to face Soviet-manufactured long-range artillery than, say, Western Germany or the US. Conversely, Soviet-equipped artillery units would face more serious problems in fighting against a Third world country fielding the new "GC45 generation" gun howitzer than the Soviet Army itself during a war in Central Europe.

A redirection on development of NATO artillery appears to be urgent. Already heavily committed to their own programmes (the M $198155 / 39 \mathrm{~mm}$ for the US, and the FH-70 $155 / 39 \mathrm{~mm}$ for Great Britain, West Germany and Italy) NATO countries have so far paid little or no attention to the very promising technologies pioneered by SRC- $Q$ and developed by ARMSCOR, PRB and WoestAlpine. ' (author's italics).

The italicized comments imply the most startling transformation of the South African artillery arm; viz the dramatic supersession of equipment which had remained static for some 30 years by a technology that is superior to that of NATO. The question of the export of this technology to Third World military forces is referred to in an article published in the SA Digest (dated 16 September 1988), reproducing a SAPA release of 7 September:

'South Africa, unlike its competitors, offers a 2,4 million package that includes a gun, a tractor to give it mobility and a fire control system. ARMSCOR also provides the extended range ammunition.

Iraq is believed to have had the G-5 for at least three years of the eightyear Iran-Iraq war, using it, together with 200 of the self-propelling automatically loading GCT $155 \mathrm{~mm}$ howitzers, as the backbone of its artillery regiments.

Both Iran and Iraq acquired large numbers of the Austrian GHN-45 gun, one of the G-5's several ancestors. Baghdad, not happy with it, however, approached South Africa for $155 \mathrm{~mm}$ ammunition. The G-5 soon followed.

Mr (Henry) Dodds (a spokesman for Defence Marketing Services in London) says he does not see any difficulty in Iran or Iraq trading with South Africa." The South Africans want oil, and the Iranians and Iraqis need artillery".'

However, Mr Dodds's approach to the marketing of G-5s to Iraq was dramatically belied by the Gulf War of 1991, when the forces arraigned against Iraq (led by Great Britain, the United States, France and Saudi-Arabia) were confronted by South African manufactured $G-5$ guns; resulting in acute diplomatic embarrassment to the Republic, which had pledged its moral support for those forces.

\section{The gun}

The following extract, from a supplement to Paratus, dated July 1979. succinctly defines the tactical profile of the weapon:

'The G5 system consists of the G5 medium gun, a family of $155 \mathrm{~mm}$ calibre ammunition and the gun tractor. These elements were developed simultaneously to culminate in one system for series production. The system will be the equipment backbone of the new South African Field Branch Artillery.

As far as the tactical features of the G5 $155 \mathrm{~mm}$ Medium Gun are concerned, it is worth noting that the 
gun will be employed in conventional and unconventional warfare to provide offensive and defensive close fire support to other "teeth" arms (ie arms of the service directly involved in combat). It will also provide independent artillery fire aimed at confusing and destroying the enemy as well as counter-bombardment fire aimed at all enemy weapon systems that might interfere with the effective use of our forces and weapons systems.

The above functions are complementary and the G5 system has the features and capabilities to be effective in any and all of its functions.

The G5 system can be employed in alternative roles. The superstructure can be remounted onto a highly mobile substructure which will enable the G5 to be used in a mechanised form. Tests indicated that the G5 has anti-tank and anti-vehicle capabilities. Concerning its tactical features, it is noteworthy that the G5 is capable of a high rate of fire...

Primary movement of the $G 5$ is by means of a gun tractor. A secondary system can be brought into effect in the form of a built-in motor which can drive the gun independently. This system simultaneously makes it easier to handle. As far as the fall of shot and shot dispersion are concerned, the $G 5$ has repeatedly and accurately fired good groupings. The fall of shot can also be accurately controlled. The gun can be transported by aircraft, train or tank-transporter.

Up to now, the effect of the SA Forces artillery fire was mostly of a neutralizing nature. With the advent of the G5, this can become destructive fire. The gun is able to fire all existing $155 \mathrm{~mm}$ projectiles. Furthermore, it can fire all fuses, most charges and all existing NATO 155 $\mathrm{mm}$ ammunition.

The G5 $155 \mathrm{~mm}$ Medium Gun is an accurate weapon, designed to give service "until the year 2000". It is sophisticated without abandoning the principles of simplicity and reliability.' (author's italics).
The italicized statement is particularly revealing, as it underscores the dramatic enhancement in the capability of artillery, motivated by South African experience of Operation Savannah.

The maximum rate of fire over a 15 minute period is three rounds per minute; two rounds per minute being possible in the sustained fire role. The weapon is operated by an eight man crew, and is normally towed by a South African built 10 ten ton vehicle (the Samil 100 gun tractor), which transports the crew, projectiles, charges and fuses. The vehicle can attain speeds of up to $90 \mathrm{~km} / \mathrm{h}$.

The Citizen (in an item entitled, Nothing quite like SA's $G-5$, contained in the issue dated 7 September 1988) quotes an eminent authority, within the sphere of artillery, with regard to the $G-5$, as follows:

\footnotetext{
"'It is exceptional", said Christopher Foss, military editor of Jane's Defence Weekly. "At high elevation it can fire a shell $40 \mathrm{~km}$. By using base bleed ammunition...the shell is steadier on its way to the target."
}

The facility to fire a shell at high elevation, exceeding the normal ranges, endows the $G 5$ with a combination role of both gun and howitzer. The article continues:

'The South Africans, unlike their competitors, offer a package that includes the gun, a tractor to give it mobility and a fire control system.'

\section{Ammunition}

ARMSCOR manufactures five types of projectile for the $\mathrm{G} 5$ :

(i) High Explosive (HE): The HE projectile exerts a terminal effect on a wide variety of targets (eg soft skinned military vehicles, prone and standing personnel), which doubles that of the standard M107 type projectile. This is achieved by the use of:-

(a) Modern high fragmentation steel.

(b) The walls of the shell, which 
ensures $23 \%$ additional volume to receive the High Explosive, compared with that available in the M107 shell.

(c) High energy explosive filling (RDX/TNT) mixture.

(ii) HE Base Bleed: The HE Base Bleed projectile (cf above) possesses the same terminal effectiveness as the HE shell. However, it facilitates a $30 \%$ increase in such effectiveness at maximum range, when compared with the $\mathrm{HE}$ shell. The dispersion of the fall of shot of the Base Bleed projectile is equivalent to that of the HE counterpart.

(iii) White phosphorus: The phosphorus projectile is essentially the same as that of the HE shell, the latter of which has been adapted for filling with white phosphorus. The white phosphorus shell is used for screening and gun ranging purposes.

(iv) Illuminating: The illuminating projectile has a light intensity of 1,65 million candella and a burning time of 90 seconds. The external ballistics of this projectile are equivalent to those of the $\mathrm{HE}$ shell.

(v) Base Ejection (BE) smoke: The BE smoke projectile is operationally employed for screening, spotting and signalling purposes. The BE carrier shell contains several smoke cannisters. The carrier shell is also fitted with the M805 electronic time fuze. The current smoke colours are white, red and blue.

\section{Specifications}

Calibre: $155 \mathrm{~mm}(6,1 \mathrm{in})$

Weight:Travelling - 13500 kg (29 762 lbs)

Dimensions:Length (travelling) - 9,10 m (29ft 10,25 in)

Width (travelling) $-2,50 \mathrm{~m}(8 \mathrm{ft} 2,4 \mathrm{in})$
Height (travelling) $-2,30 \mathrm{~m}$ ( $7 \mathrm{ft} 6,55 \mathrm{in}$ ) Maximum rate of fire: 3 rounds/ minute for 15 minutes; thereafter 2 rounds/minute for one hour.

Elevation: $+73^{\circ} / 3^{\circ}$

Traverse: total $84^{\circ}$

Maximum range: $30000 \mathrm{~m}$ with normal HE projectiles; $39000 \mathrm{~m}$ with Base Bleed projectiles.

THE G-6

\section{Development}

Although the provision of the G-5 endowed the South African artillery arm with much-needed fire support, it yet failed to meet the urgent requirement for a highly mobile support system able to be rapidly deployed in distant border areas. The problem had clearly emerged during Operation Savannah, in which the artillery experienced great difficulty in keeping pace with the infantry and armour. In response to this need, ARMSCOR decided upon the development of a self-propelled gun, specifically orientated to a southern African military scenario. Although NATO self-propelled guns (eg the M109, SP-70 and GCT) as well as those of Soviet and East European design, depend on tracked vehicles as their prime movers, the South African Army required a weapons system that could keep pace with infantry and armoured car units participating in the pre-emptive strikes that characterized the SADF's offensive strategy during the first half of the 1980s (cf Preface). Within this context, one authority states: ${ }^{9}$

'Self-propelled guns and howitzers, both of Western and Eastern design, are nearly invariably tracked vehicles (often based on MBT chassis), and are mainly intended to provide fire support for large armoured and mechanised units. Tactical mobility (that is, crosscountry mobility) is consequently judged far more important than strategic mobility, and the self-propelled systems are usually transported to just behind the (front line) on railway carriages or large tank transporter semi-trailers.

9 G-5 and G-6: South Africa does it (almost) by itself. Military Technology, 1/83 


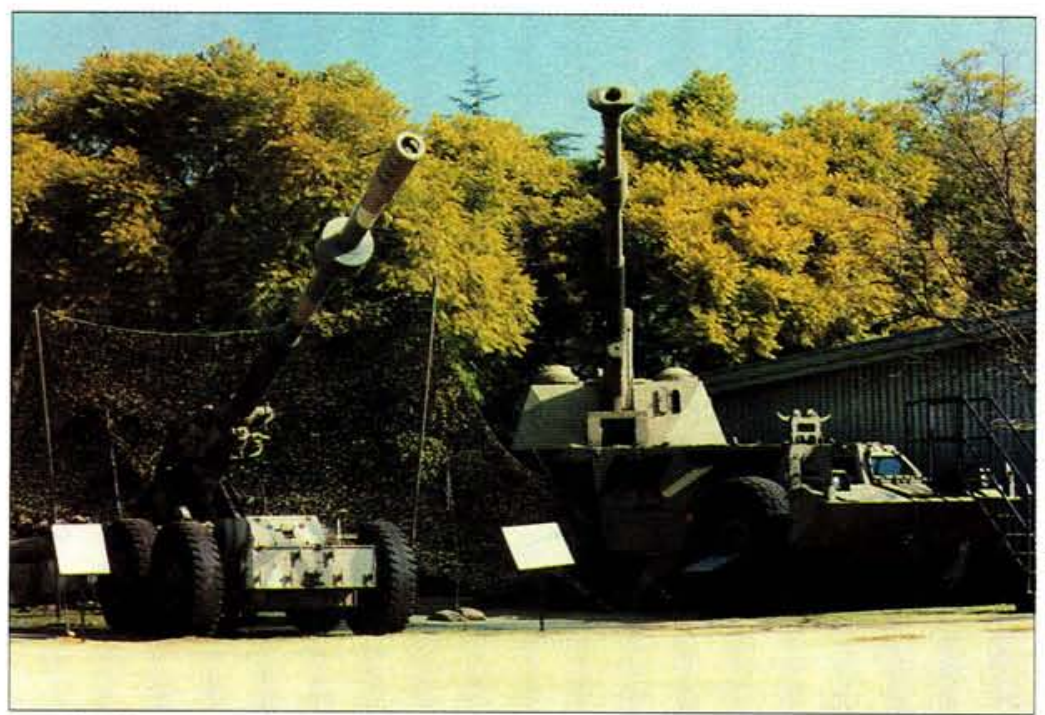

Self-propelled G6 $155 \mathrm{~mm}$ gun-howitzer (on right), flanked by the G5 (left)

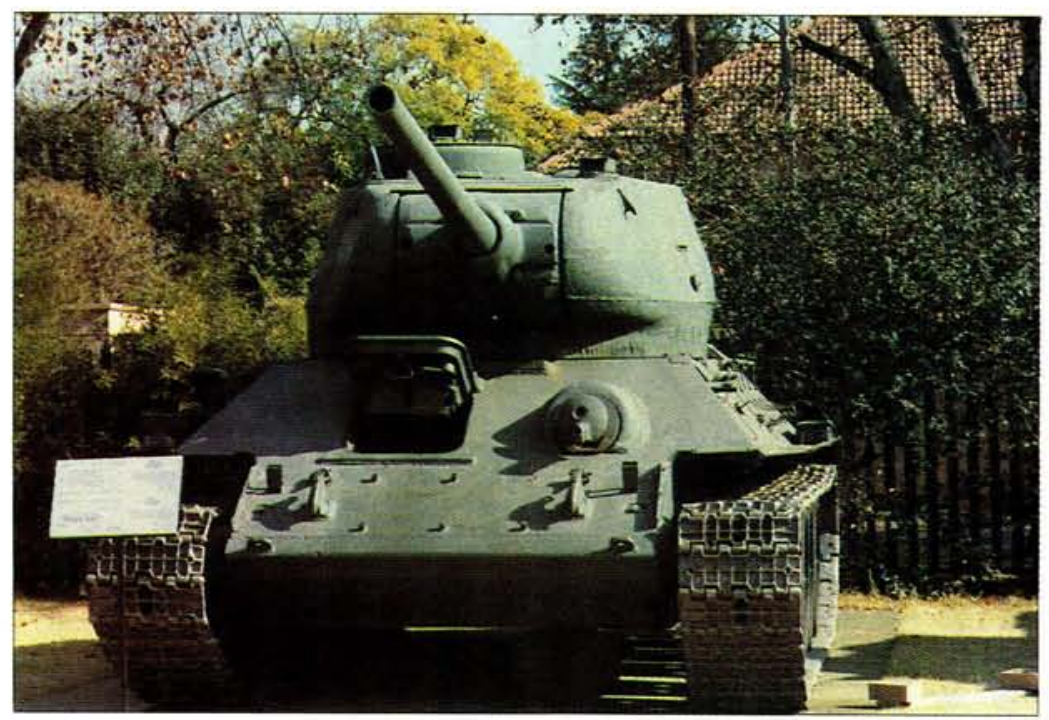

Russian T34 Tank

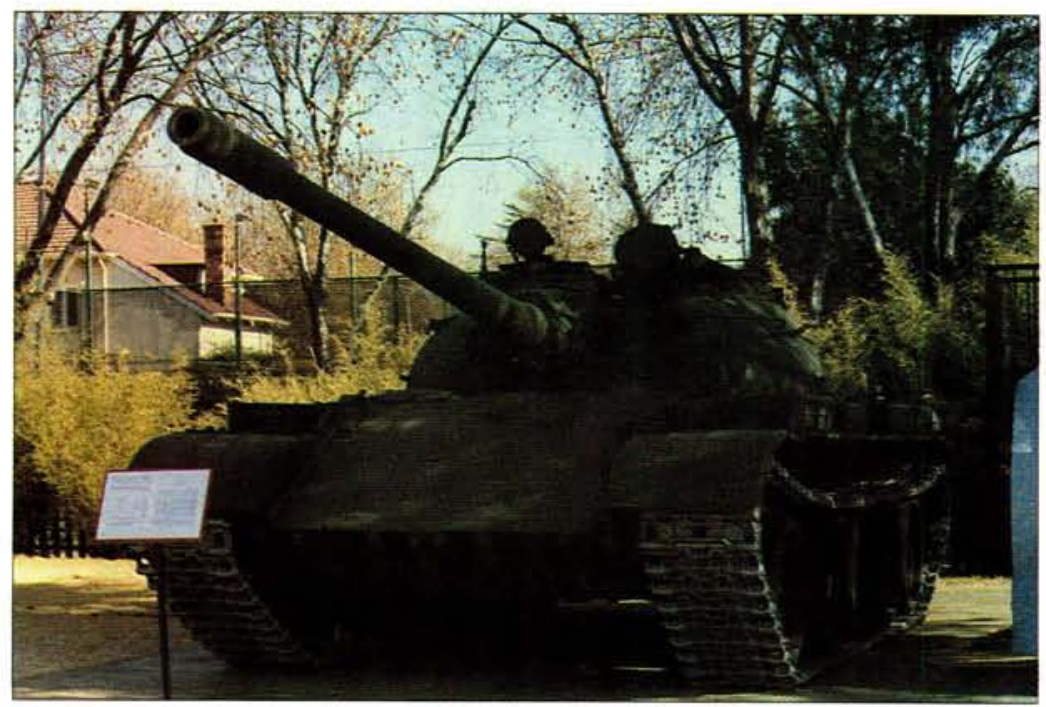

Russian T55 Tank.

The guns and tanks shown above are on display at the SA National Museum of Military History, Saxonwold, Johannesburg 
On the contrary, the South African Army needed a system to provide fire support to its mechanised infantry units (now equipped with ELAND armoured cars and RATEL wheeled ICVs (infantry combat vehicles)) during their intervention raids, nearly always carried out with little or no warning and over...very long distances from bases. Consequently, the required vehicle should be able to keep pace with ELANDS and RATELs over many hundreds of kilometres; the accent was therefore placed on strategic, as opposed to tactical, mobility. What matters is not the cross-country performance, but rather the capability to move at high speed over unpaved roads or open, flat countryside without requiring special transport equipment.

On the basis of these requirements, the already challenging technical problems of completely developing a selfpropelled system within South Africa was made even more difficult with the decision to design a wheeled vehicle. wheels offering better strategic mobility than tracks. Before the G-6, the one and only wheeled self-propelled gun/howitzer operational all over the world was the Czechoslovakian DANA $152 \mathrm{~mm}$, based on a Tatra $8 \times 8$ KOLOSS truck chassis.

A self-propelled gun mounted on a tracked chassis would obviously generate major problems in relation to the speed of mechanized columns. Overlaying this vital consideration was the need for the highest possible degree of mobility; obviating the need for tank transporters to convey the fire support system to positions immediately behind the front line. Such tank transporters are commonly used for this purpose in other theatres.

The factors cited above shaped ARMSCOR's decision to manufacture a wheeled vehicle as the prime mover of the self-propelled gun. In addition to the overriding advantages of strategic mobility, the wheeled chassis resulted in a $60 \%$ reduction in fuel consumption, when compared with a tracked transporter: in addition to a reduction of $50 \%$ in initial costs, as well as a trebling of the life of the equipment and reduction by one third of the intervals between overhauls.
Development of the G-6 commenced in 1978, and a little over four years later ARMSCOR was able to deliver the first prototype to the SADF for evaluation and testing.

\section{The gun}

The $G-6$ is a self-propelled six-wheeled gun that can be employed in the indirect role as a gun, howitzer and mortar; as well as possessing a direct capability of up to $5000 \mathrm{~m}$. The weapon is popularly known as the 'Rhino', and has a mass of 36 tons; is $10 \mathrm{~m}$ in length and $3,25 \mathrm{~m}$ wide at the turret roof. The Rhino is undoubtedly the heaviest and largest wheeled combat vehicle extant. In order to properly distribute this weight, and in order to meet the pre-requisite for low ground pressure (thus facilitating easy movement over sand), the vehicle is fitted with enormous $21 \times 25$ runflat tyres. These tyres are of the type used in some very large earth moving vehicles. The tyres of the G-6 are equipped with a centralized pressure control system. The gun howitzer which is transported on this chassis is virtually the same as the towed G-5 gun-howitzer (cf above) and fires the same range of ammunition, with identical performance. The gun is mounted on a very large and spacious armoured steel turret, positioned at the extreme aft of the vehicle. This turret is fully traversible, but firing by means of the semi-automatic loading system, which is capable of a rate of fire of four rounds per minute, is only possible on a frontal arc of $40^{\circ}$ on each side. Secondary armament is provided in the form of a $12,7-\mathrm{mm}$ machine gun fitted to the cupola (600 rounds).

Emphasis has been placed on the protection of the crew of five (commander, driver, gunner, loader and ammunition handler), with firing ports to enable small arms to be utilized in the event of ambushes. In addition. the 'Rhino' has been designed to withstand mines; being fitted with blow-out holes, enabling the blast to be vented in an upwards direction. Powered by an air-cooled turbo-charged diesel engine, the $G-6$ can attain speeds in excess of $90 \mathrm{~km} / \mathrm{h}$ on a road and $45 \mathrm{~km} / \mathrm{h}$ cross-country. The operational range is in excess of $400 \mathrm{~km}$. 
The Business Day (14 May 1987) records the opinion of the highly esteemed and authoritative Jane's Defence Weekly with regard to the G-6:

'SA's G6 155 mm self-propelled howitzer was yesterday described as "one of the best artillery systems in production" by Jane's Defence Weekly, the world's leading arms journal.

A detailed five-page examination of the G-6, the only self-propelled system of its sophistication and power outside the Warsaw Pact, could find no serious criticism of the weapon.

Jane's said many ARMSCOR's products were now being sold overseas in increasing numbers - with advertisements regularly carried in the journal. Equipment sold included RATEL IFV's to Morroco, Buffel mine protected vehicles to Sri Lanka and the G5 to Iraq (cf above).

Jane's said while the G6 had been developed specifically to meet SA artillery requirements, it would be offered for export at an early date.

It said: "Like the earlier G5, the G6 is unique in that the customer can purchase a complete artillery system from just one source as well as being provided with a full training package."

The journal said the updated G6, which has a burst fire rate of three shells every 21 seconds and can hurl $47 \mathrm{~kg}$ missiles across $39000 \mathrm{~m}$, had sufficient improvements on previous models developed since 1981. It mentioned night sights, conveyer belt loading, double armoured flooring, air conditioning for the crew, bullet proof windows with $180^{\circ}$ visibility, tyre efficiency, speed up to 70 $(\mathrm{km} / \mathrm{h})$, fully independent suspension and visible and audible alarm systems.

\section{Support systems}

Both the G-5 gun howitzer and G-6 selforopelled gun are supported by three extremely sophisticated systems in relation to fire control, range-finding and communications.
The AS80 artillery fire control system has been designed for utilization by both the G-5 and G-6 gun platforms. It is a decentralized computerized system capable of managing the fire control computerization for a fire unit of up to eight guns (ie a battery). The system will control up to four simultaneous engagements, within each of which four distinct phases are provided; ie

(i) Initial order, for the definition of the fire mission;

(ii) Adjustment of fire on the target:

(iii) Fire for effect, where data is calculated for each participating gun:

(iv) End of mission.

All interaction between the user (in the fire control post) and the AS80 system occurs through the medium of a dialogue in which the system prompts the user with available alternatives. The dialogue is programmed to conform to the normal manual fire control procedures; it is available in two languages and can be translated in accordance with the user's requirement. The system includes provision for gun display units, as a means of feeding data to the guns. The gun display units can be mounted directly on the guns, or placed upon a tripod at a convenient location near the gun. Communication between the fire control system and the gun display units is effected either by radio or landline.

Another significant system serving both the G-5 and G-6 is a device for the continuous measurement of muzzle velocities. This system is designated the EMVA MK 10B Muzzle Velocity Analyser, and is a Doppler radar measuring instrument capable of measuring projectile velocities in the range of $30 \mathrm{~m} / \mathrm{s}$ to $3000 \mathrm{~m} / \mathrm{s}$. Results are presented in metres/seconds for direct application by the gun crew. The instrument consists of an antenna head suitable for installation on the gun, and a processor unit (including a printer). In addition to the print-out of the muzzle velocity, the instrument is also capable of printing all the measurement results.

The third system is the $\mathbf{S 7 0 0}$ meteorological ground station system. This is 
an independent self-contained system which automatically tracks, receives and processes radiosonde data from the point at which the projectile is launched until termination of flight. The system is usually mounted in an airconditioned container cabin, transported on a mobile trailer. The received data is converted into actual meteorological information which is recorded on both magnetic tape and directly on a chart recorder. Throughout the flight, the 5700 tracks the sonde, furnishing, on the basis of its information, details of wind velocity and direction at various altitudes.

\section{THE VALKIRI 127-MM ARTILLERY ROCKET SYSTEM}

The third artillery support system which is rooted in the South African experience of the Angolan War of 1975-1976 is the $127 \mathrm{~mm}$ multiple rocket launcher (MRL), commonly referred to as the Valkiri. Its design and production were motivated by the desire to counter the Soviet BM-21 rocket launcher. Initial development of the Valkiri commenced in November 1977, and the development programme was completed in March 1981. Series production was initiated in April of that year. In August 1981 (only four months after the commencement of series production) Valkiri was deployed operationally, for the first time and with great success, during the course of Operation Protea.

The Valkiri is a highly mobile artillery rocket system, capable of directing high rate saturation fire on area targets at ranges of between 8 and 22 $\mathrm{km}$. In essence, the Valkiri artillery rocket consists of a $24 \mathrm{pr}$ tube pack mounted on a light 4 -ton $4 \times 4$ petrol driven vehicle. The rockets can be fired singly or in ripples of between two and 24 from within the cab of the vehicle by means of an electronic firing unit mounted within the cab; or, alternatively, by remote control through the medium of a unit which can be connected to the launcher via a $50 \mathrm{~m}$ plug-in cable. A radio facilitates communication with the command post controller, with a remote control of the firing unit. The rate of fire is 60 rounds per minute, either individually or in programmed ripples of between two and
24 rockets. The reload time is less than 10 minutes for a full salvo. Once positioned, it requires only some five $\mathrm{min}$ utes to bring the system into action. The power for the rocket system is derived from the power take-off or batteries for the vehicle. To ensure stability, the rockets are fired from the side tubes of the launcher first, those in the centre being fired last. The sight, in accordance with conventional artillery techniques, is mounted in the side of the launcher and stored in a special container within the vehicle when not in use.

The rocket is $2,68 \mathrm{~m}$ in length and is fitted with a pre-fragmented anti-personnel warhead and radio-proximity fuse. The warhead consists of a matrix of some 8500 steel balls and epoxy resin cast into a thin walled cylinder. The proximity fuse is screwed into the front of the warhead. Spoiler rings of three different sizes are provided. These fit onto the nose of the rockets and are used to increase the wind resistance and thereby reduce the range; the degree depending on the size of the rings. These rings generate a terrifying scream as the rocket flies towards the target; thus greatly compounding the morale lowering factor of this weapon. The proximity fuse, developed specifically for the $127 \mathrm{~mm}$ MRL, operates as a ground surface proximity detector and is frequently agile, rendering it unaffected by terrain reflectivity and approach angles, and virtually immune to enemy jamming. It possesses a direct action back-up device.

The Valkiri embodies one major advantage over virtually all similar systems. This is the rocket system's mounting on a standard two-ton truck, which is not only lighter and more agile than the larger trucks normally utilized in this role, but offers greater strategic mobility by ensuring that the system is fully air-transportable in C-130 and C-160 aircraft. The truck is also fitted with a canvas tilt, presenting the appearance of a normal two-ton truck when seen from a distance or in reconnaissance photographs. The camouflage aspect of the system is thus greatly enhanced. A collapsible ammunitioin stowage assembly to accommodate 48 rockets 
and fuses has been developed to fit the Standard Samil 50 ton truck, thereby providing readily accessible spare ammunition.

The MRL incorporates a meteorological guidance support system. This consists of several components: a weather balloon; a weather vane and an emo-meter mounter on a telescopic mast in close proximity to the launcher; these determining weather conditions. In addition, a wind gun is provided. This fires a small calibre projectile, which estimates prevailing ground wind conditions.

It is widely believed that the Valkiri system is more effective than its NATO counterpart, the Vought system, as the former has 24 rockets (as opposed to a maximum of 12 fired by the latter); as well as being simpler and less expensive. The Valkiri system can be deployed either independently or in support of conventional artillery guns directed against such target areas as camps, troop concetrations and softskinned vehicle parks. Due to its high mobility, it is ideally suited to the 'shoot and skoot' principle of deployment; ie to bombard the enemy and then retreat to a safe position as soon as possible before he can retaliate.

\section{THE OLIFANT MARK IA ${ }^{10}$}

To reiterate, in Angola throughout the major part of operations launched by the SADF in the 1980s, the South African armoured capability was vested entirely in the armoured car and Ratel. Centurion tanks had been brought from Great Britain during the 1950s, but approximately half of this fleet (100) was sold to Switzerland, during the 1960s, at a time when it was felt that there would be no need for a main battle tank (MBT) in any future military context involving South Africa. However, a number of additional Centurions (some 200) were brought in varying states of repair from Jordan and India in the late 1970s, symptomatic of a renewed awarnesss of the need to develop the Army's tank fleet to a formidable size. A fleet of approximately 300 tanks was thereby created. These Centurion tanks have subsequently been modernized in or-der to increase their mobility and firepower. The Olifant is the end product of such enhancements.

Mobility and reliability have been considerably upgraded by fitting a more powerful diesel engine in place of the original petrol engine, a new transmisssion and improved supspension. The Olifant has a road speed of $45 \mathrm{~km} / \mathrm{h}$ and a road range of $250 \mathrm{~km} / \mathrm{h}$. Its off road (ie cross-country) speed and range is $30 \mathrm{~km} / \mathrm{h}$ and $200 \mathrm{~km}$ respectively.

With regard to armament, the Centurion's $20 \mathrm{pr}(84 \mathrm{~mm})$ gun has been replaced by a South African $105 \mathrm{~mm}$ gun, developed from the well-proven British L7 $105 \mathrm{~mm}$. The new fire-control system includes a laser range finder and passive night fighting equipment. The tank's secondary armament conists of one $7,62 \mathrm{~mm}$ machine gun, coaxially positioned, and the $7,62 \mathrm{~mm}$ machine gun mounted in the commander's cupola. In addition, eight 81 $\mathrm{mm}$ some grenade launchers are carried. The ammunition comprises 72 rounds of $105 \mathrm{~mm}$ ammunition and 5 600 rounds of $7,62 \mathrm{~mm}$ ammunition.

The Olifant cannot totally compete with the current generation of MBTs, but it is nevertheless a very capable fighting vehicle which can outmatch all other counterparts at present in southern Africa.

It hull and suspension has served as the basis of an armoured recovery vehicle. The recovery vehicle is fitted with a front-mounted spade cum dozer blade and winches. The usual selection of tools and equipment is carried.

\section{The Olifant in Angola 1987-1988}

The fighting in Angola during the period 1987-1988 saw the South African army deploy tanks for the first time 


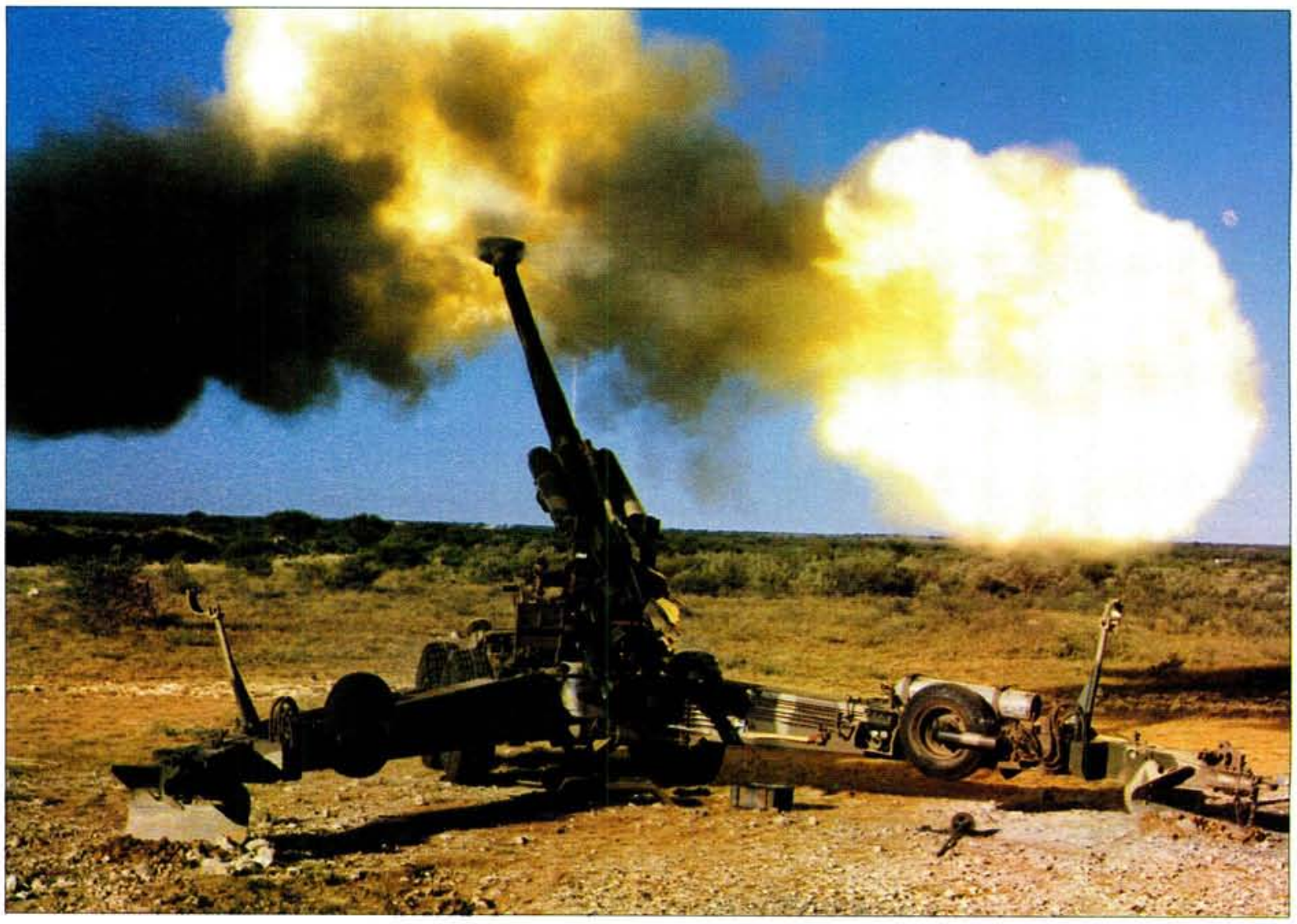

The G5 155mm Gun (above) and Olifant Tank (below) in action

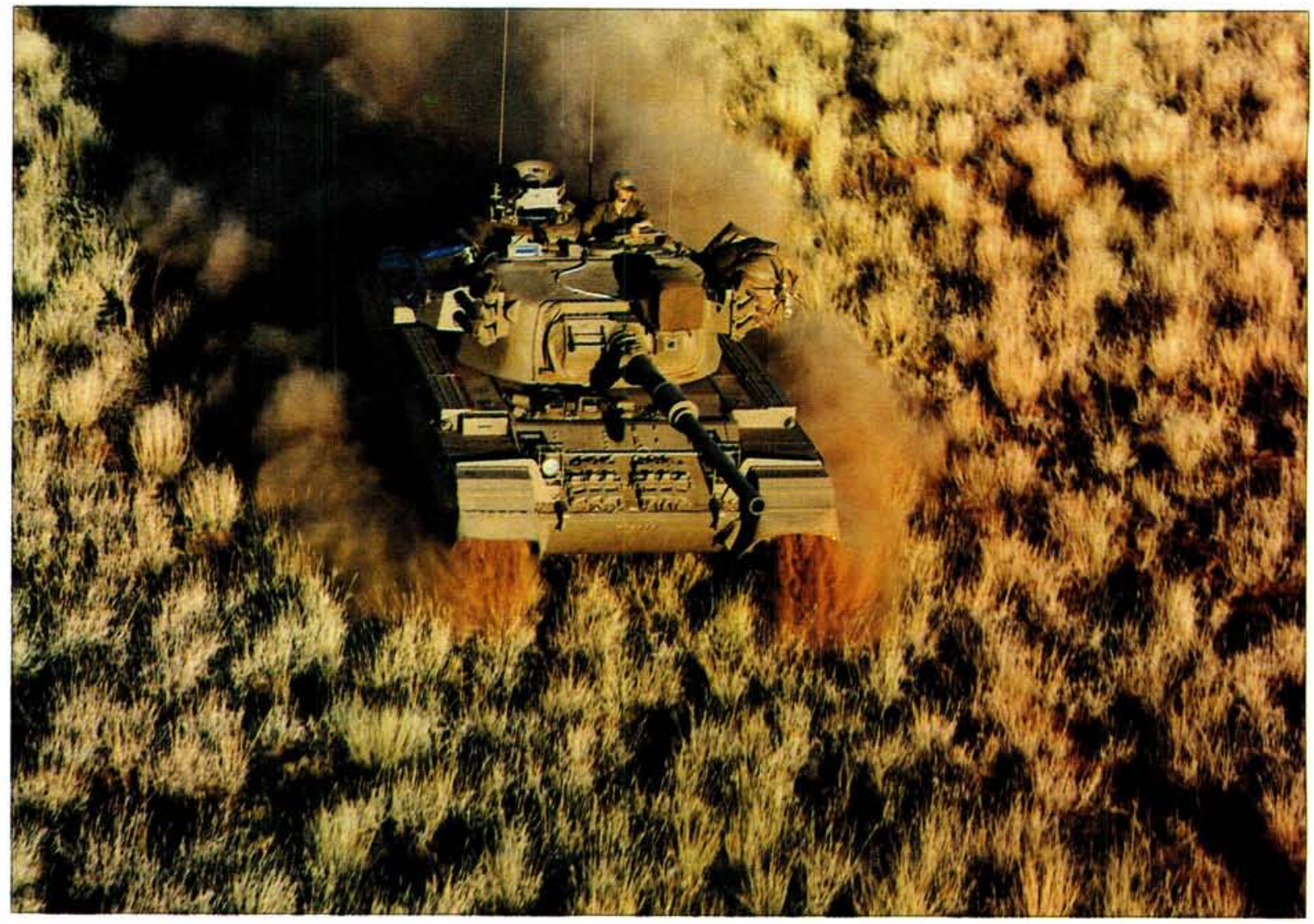

(Photo's: SADF Photo Collection) 
since 1945. The operations revealed that the tank was capable of fulfilling all the exacting demands imposed upon it. The Olifants had to contend with dense bush and sand and were used to clear a way through the bush for other vehicles. This tank proved the most effective vehicle in such unsuitable conditions and, in this respect, merits a most favourable comparison with the American $\mathrm{M}-48$ in Vietnam. Heavy, powerful and extremely resilient, the Olifant proved to be the only combat vehicle capable of overcoming extremely dense bush; its effectiveness in this sphere, during these operations, only rivalled by the three pre-production G6s. Some of the Olifants involved covered in excess of some $2500 \mathrm{~km}$ on their tracks, traversing the dense bush and often deep sand of south-eastern Angola, remaining operational despite a shortage of spare parts. It is important to bear in mind that thick bush can present a most formidable barrier, even to modern combat vehicles. In one instance the bush was so dense that the 56 ton Olifant was only able to cover some 800 metres in four hours. The lighter Ratel suffered to an even greater extent.

The actual fighting in these operations, from the vantage point of the South African MBT presented, arguably, fewer demands upon the tank in comparison with the task of reaching the objective. The enemy threat consisted, in the main, of the $T-54 / 55$ series of tanks (cf Part I) and a variety of antitank weapons; principally the $82 \mathrm{~mm} \mathrm{~B}$ 10 (cf Part I), RPG missiles and some Sagger wire-guided missiles (cf Part I). The Fapla and Cuban trained tank crews did not provide any serious opposition, least of all to the Olifant. Only one South African tank appears to have been damaged by them, being struck on its idler by a $100 \mathrm{~mm}$ shell. In return, the Olifant crews destroyed at east $32 \mathrm{~T}-54 / 55 \mathrm{~s}$. The $105 \mathrm{~mm}$ shells of the Olifant had, predictably, no probems in confronting their armoured adversaries. One APFSD projectile passed through the sand wall piled in front of a dug-in T-55 and then penetrated its glacis plate. The armour piercing shells also penetrated enemy armour at some very shallow impact angles that resulted from the close action engage- ments. The $105 \mathrm{~mm}$ HEAT shells also dealt effectively, and without difficulty, with the T-55s. The gun control system proved reliable and clearly met the demands of rapid encounters fought at close range. The fire control system, however, was not truly tested in the 1987-1988 operations. The majority of the armoured clashes were effected at such short ranges that quick, almost instinctive, shooting proved to be the rule.

The various enemy anti-tank weapons singularly failed to achieve any success againt the Olifant; although some of the South African tanks were hit without incurring any damage. The 122 $\mathrm{mm}$ D-30s deployed by the Fapla brigades (cf Part I) did not utilize their effective HEAT rounds in an anti-tank role. Thus, the Olifant's armour protection was not tested in these operations; its ability to absorb non-penetrating damage was adequately demonstrated by the small numbers that were hit. The BM-21 multiple rocket launcher (cf Part I), by contrast, confronted the advancing South African tanks in a direct fire mode on several occasions. In one case a rocket tore the idler and track off an Olifant, although the tank suffered little other damage. In one instance a normally fired $127 \mathrm{~mm}$ rocket killed a tank driver when it struck the Olifant on its front armour before he could close the hatch securely.

However, anti-tank mines presented a considerably more formidable threat to the Olifant. It was finally a minefield, well covered by artillery, that halted the last attack on the remaining Fapla toehold east of the Cuito River. In the course of this action three Olifants were disabled by mines, suffering track and suspension damage. They could not be recovered and were later captured by Fapla forces. These were the only South African tanks lost in the operations. None were destroyed in the actual fighting, nor suffered any armour penetration.

\section{THE 1990s USHER IN \\ DEMILITARIZATION: IMPACT UPON THE SADF AND ARMSCOR}

The political configuration of the decade (ie the 1980s) which witnessed the climax of this intense phase of op- 
erational activity has undergone a drastic transformation at the outset of the 1990s. The following quotation from the article referred to (7) is deemed apposite:

'(The SADF Memorial at Fort Klapperkop symbolizes) the high profile assumed by the armed forces (of South Africa) at a point in time when (the Republic) was confronted by hostile forces within (its territory). The unveiling of the Defence Force Memorial (on 31 May 1979) occurred during a most intense and aggressive phase of activity on the part of the South African armed forces, directed towards the defence of South West Africa...against SWAPO insurgency and the extension of that conflict into Angola. Today the entirely different military configuration of Southern Africa (including the independence of Namibia (as South West Africa is now termed) under a SWAPO government) has effectively sealed this phase of the SADF's history. Thus, it is extremely improbable that South African forces will ever again enter Namibia and Angola with hostile intent.'

An index of the far lower profile assumed by the SADF during the present decade is the scaling down of mechanized infantry battalions. For example, within the former 72 Brigade, the SA Irish Regiment, having been converted to mechanized infantry during the second half of the 1980s, no longer serve in such a role. Similarly, the brigade structure has been phased out. Thus, 72 Brigade has been dissolved and, in common with all other brigade groups, have been absorbed into a division (in 72 Brigade's instance 7 Division), which now forms the central organizing, administrative nucleus for the individual citizen force units encompassed by their respective divisions.

These developments - the scaling down of mechanized infantry battalions and the dissolution of the brigade groups are clearly symptomatic of the reversal of the aggressive orientation and image of the SADF during the 1980s. The process has its counterpart in the very considerable attenuation in the image and role of the South African armaments industry - ARMSCOR.

The dramatically altered political configuration of Southern Africa which emerged at the outset of the succeeding decade exerted a profound impact upon the industrial partner of the armed forces - ARMSCOR - in the relationship that was climaxed during the preceding era. The character and force of that impact forms the theme of an article entitled. The armaments industry - a white elephant?, by Frank Sutherland". The writer comments:

' Over the last year or two, there have been major changes in the political and business environment of the ARMSCOR and the South African armaments industry...the ending of the war in Angola and the dawning of "a world peace era" are well known. These events have affected the armaments industry in various ways, the most visible and painful being a sharp reduction of orders and concomitant cutbacks in production and staff. A less visible but highly pertinent effect has been a major change in the arms industry's public image...

In the previous era, until the end of the Angolan war, ARMSCOR and the industry it led had an image which can only be described as excellent. This image was not undeserved, for the country had to contend with the compounded problem of a protracted border war and an international arms boycott. Because of the success of the armaments industry in providing the defence force with virtually everything it needed, it acquired an image of "saviours of the nation". The public realized that there was no option but for South Africa to produce her own armaments, and national expenditure on defence was in any case quite average by world standards. The unveiling of products such as the Valkiri rocket system, the G5 and G6... (the Ratel) etc, caused a swelling of the national pride, and ARMSCOR came to be regarded as a well-managed firm of technological experts...

"Sutherland, Frank. The armaments industry - a white elephant? Salvo, 90/4, pp 21-24. 
Then the war ended. This meant that the local market for ARMSCOR's products was drastically reduced - a fact which by itself would have had a profound effect on the fortunes of the arms industry. The effect was compounded by the government's fundamental shift in its financial priorities: to achieve workable new dispensations, resources previously spent on arms would have to be spent on social upliftment.

The nett result was a demilitarising of the country and a reappraisal of ARMSCOR by the public and the media...(Some elements of the media) considered that ARMSCOR and certain other parastatals such as the Atomic Energy Corporation...had become white elephants, and said it in so many words. These organizations, they argued, were created when there was a great need for self-sufficiency in the face of sanctions, but they were expensive and the evolution of the new South Africa was making them redundant...

\section{Such opinions were not expressed} only by the media.

During the October (of 1990), the Pretoria News reported that the Synod of the Anglican diocese of Cape Town had decided that the SAD Defence Force and Umkhonto weSizwe should both be disbanded in a post-Apartheid South Africa, and that, inter alia, ARMSCOR and "other arms manufacturers" should be dissolved.

The image of the arms industry had indeed changed. '

\section{An ideal historical vantage point}

For the reasons cited above, this study is ideally placed in point of time; presenting a survey of the major operational developments within the South African Army, which occurred during an era which now appears encapsulated or sealed in time. Thus, no longer being in a state of flux the technological revolutions in artillery and mechanized infantry which characterize the 1980s may be viewed with a certain degree of finality; within a perspective which has been enclosed or framed, so to speak.

\section{CONCLUSION}

Two points may, perhaps, be made in conclusion. First, perhaps the most remarkable feature of the military-industrial complex that emerged during the latter half of the 1970s and 1980s was the manner in which it created a weapons technology that transcended an entire generation in totally closing the distance between South Africa and NATO in this sphere; to the extent that the former could most successfully compete with the western nations in the export field. Second, the development of the Republic's military technology during the 1980s is pervaded by a curious irony. This aspect is exemplified by the G5, G6 and Olifant. For these embodiments of South Africa's vast technological strides in the fields of artillery and armour were deployed in action for the very first time during the 1987-1988 operations in Angola; and these occasions may well, perhaps, mark the final instance in which they were thus used; in the light of the drastically altered political stance of Southern Africa, commented upon above. This process is paralleled by the situation of the former mechanized infantry battalions of 72 Brigade. Having experienced the arduous and taking process of conversion, they were overtaken by current political developments, and proved the victims of 'rationalization'; a facet of the demilitarization process.

* Dr Monick is Curator of Medals and Numismatics at the South African National Museum of Military History. He is the author of numerous articles relating to medals and military history, which have been published in a wide variety of journals in both South Africa and the United Kingdom. Dr Monick has also authored several books, relating to both medals and regimental histories (ie those of the Witwatersrand Rifles and the South African Irish Regiment), as well as general works, which have been published in this country.

\section{BIBLIOGRAPHY: SOURCES REFERRED TO IN TEXT}

(1)Monick, S. Silent voices of time: a selective study of the sculpture of the South African National Museum of Military History. Militaria 21/ 4. 1991, p 32.

(2)The sources of the following details concerning 
the Ratel are:

(a) Kleinecke, H W. The Ratel. Militaria $15 / 1$, 1985, pp 33-34.

(b)Fosse, C F. Jane's Armoured Personnel Carriers. London: Jane's Publishing Co., 1985, pp 101-105.

(3)Bradford, Z B. Motorised infantry on the modern battlefield. Armed Forces (SA), Vol 1 No 5. May 1976, p 16. (Reprinted by kind permission of Infantry).

Note: An extract from the USAIS Tactics Department paper Mechanized infantry on the modern armoured battlefield, prepared by Col Z B Bradford and members of the Tactics Department. The paper was disseminated to senior American military officers in October 1975.
(4)Comdt I Rimmer; conversation with S Monick: 3 October 1991

(5)Ibid item (4) above.

(6)lbid item (4) above.

(7) lbid item (1) above.

\section{Other sources referred to:}

(1)Paratus, October 1981, pp 68-71: February, 1984, pp 34-43: December 1987, pp 10-15.

(2)Heitman, Helmoed-Röhmer. War in Angola: the final South African phase. Gibraltar: Ashanti Publishing, 1990, pp 357-364.

(3) Jane's Armour and Artillery. 1979-1980; 1987 1988. 